\title{
Beyond VEGF: The NOTCH and ALK1 Signaling Pathways as Tumor Angiogenesis Targets
}

\author{
Olivier Nolan-Stevaux and H. Toni Jun \\ Amgen, Inc. \\ USA
}

\section{Introduction}

The clinical validation of several anti-angiogenic agents targeting the VEGF pathway for the treatment of metastatic colorectal cancer (Hurwitz et al., 2004), non-small cell lung cancer (Sandler et al., 2006), hepatocellular carcinoma (Llovet et al., 2008) and metastatic renal cell carcinoma (mRCC) (Motzer et al., 2009) has provided evidence that angiogenesis inhibition can lead to increased overall patient survival. Although these treatments achieve sustained tumor regression in isolated cases, the average clinical gains from individual therapeutics are measured in only weeks to months. In most patients, cancer progression resumes following initial disease stabilization as tumors acquire resistance to anti-angiogenic agents (Ellis and Hicklin, 2008; Rini and Atkins, 2009). In some disease, such as metastatic breast cancer (Miller et al., 2007), the clinical benefits from VEGF-targeted therapies appear marginal from the outset, while still other cancer types, such as melanoma (Hauschild et al., 2009) and pancreatic ductal adenocarcinoma (Kindler et al., 2007), appear to be refractory to anti-angiogenic drugs from the outset and are deemed "intrinsically" resistant (Bergers and Hanahan, 2008).

Acquired and intrinsic resistance to VEGF-targeted therapies stem from multiple proangiogenic mechanisms: VEGF signaling upregulation (Rini and Atkins, 2009); secretion of alternative angiogenic factors (Casanovas, 2011; Kopetz et al., 2010; Loges et al., 2010); acquisition of new blood vessels in an angiogenesis-independent manner via vasculogenesis, vessel co-option or vascular mimicry (Kerbel, 2008; Loges et al., 2010); and activation of stromal components such as myeloid cells and cancer associated fibroblasts, which can cooperate to rescue or expand the tumor vasculature (Bergers and Hanahan, 2008; Crawford and Ferrara, 2009). To overcome acquired resistance mechanisms, some clinicians currently shift patients from one VEGF-targeted therapy to another and are able to achieve lasting clinical benefit at least in the case of metastatic renal cell carcinoma (mRCC), suggesting that upregulation of the VEGF signaling pathway itself is one of the major initial routes of resistance in this cancer type (Rini and Atkins, 2009). However, all cancers eventually acquire resistance to even the most potent VEGF receptor inhibitors, underscoring the need for additional anti-angiogenic therapies targeted at alternative signaling pathways to overcome these resistance mechanisms.

In this chapter, we will review two signaling pathways that play critical functions at distinct phases of angiogenesis and against which experimental drugs are currently in development: the NOTCH and BMP9-ALK1 signaling axes. In each case, we will present the genetic and experimental evidence demonstrating the function of these signaling axes in angiogenesis, 
the signal transduction events they mediate during angiogenesis and the pre-clinical evidence indicating that targeted inhibition of these pathways leads to the disruption of tumor angiogenesis and decreased tumor growth.

\section{Function of NOTCH signaling in angiogenesis}

Named after the notched wing appearance of its Drosophila phenotype (Mohr, 1919; Morgan and Bridges, 1916), the NOTCH pathway is a highly conserved signaling system that plays a role in multiple critical processes, including stem cell maintenance, pattern formation, and cell fate determination. In vertebrates, this signaling system is comprised of four NOTCH receptors, and five trans-membrane ligands. This section will summarize the data that demonstrate the role of individual members of this signaling pathway in vascular development and discuss the evidence that suggests that $\mathrm{NOTCH}$ signaling may represent an attractive point of therapeutic intervention for angiogenic therapy.

\subsection{Expression of NOTCH receptors and ligands in endothelial cells and in tumors}

Expression analysis of the NOTCH signaling pathway in human cancer samples provides encouraging evidence of a role for $\mathrm{NOTCH}$ signaling in human disease. Expression of the NOTCH ligand Delta-like 4 (DLL4) is upregulated in human breast cancer and not found in normal breast tissue ( $\mathrm{Li}$ et al 2007). Similar studies have also demonstrated an upregulation of DLL4 expression in the tumor endothelium of clear cell renal cell carcinoma (CC-RCC) patients compared to normal kidney vasculature (Figure 1; Patel 2005) as well as in bladder carcinoma compared to normal bladder tissue (Patel et al., 2006). Mouse studies corroborate a role for DLL4 in the tumor vasculature. In a mouse reporter line where LacZ expression is driven by the DLL4 promoter, there is preferential expression in the tumor vasculature of implanted Lewis lung carcinoma tumors compared to the adjacent normal vasculature. Interestingly, a VEGF-Trap molecule that induces a VEGF signaling blockade effectively blocks the upregulation of DLL4 in the tumor vasculature of C6 glioma xenograft tumors, suggesting that DLL4 upregulation may be VEGF dependent (Gale et al., 2004; NogueraTroise et al., 2006).

The NOTCH ligands may also signal from the tumor itself to the vasculature. Jagged1 (JAG1) expression in head and neck squamous cell carcinoma (HNSCC) cell lines is upregulated in response to multiple growth factors, such as HGF, EGF, and TGF-alpha, pathways that are commonly altered in human cancer. In an HNSCC xenograft model, tumor expressed JAG1 enhanced neovascularization and tumor growth in vivo, and correlated with vessel content and disease progression, suggesting JAG1 may signal from the tumor to the tumor vasculature via murine $\mathrm{NOTCH}$ expressed on ECs (Zeng et al., 2005). There have also been reports of tumor expression of DLL4 in colorectal cancer (Jubb et al., 2009), although it has been hypothesized to play a direct role in cancer stem cell survival rather than tumor signaling to the endothelium (Hoey et al., 2009).

\subsection{Functional role of NOTCH receptors in developmental angiogenesis}

The phenotypes associated with genetic alteration of individual components of the NOTCH signaling pathway validate a role for multiple pathway members in embryonic vascular development. Each of the NOTCH receptors is expressed in the mouse vasculature and deletion of some individual NOTCH receptors show embryonic lethality, demonstrating non-overlapping functions during development. For example, NOTCH1 null mice are 


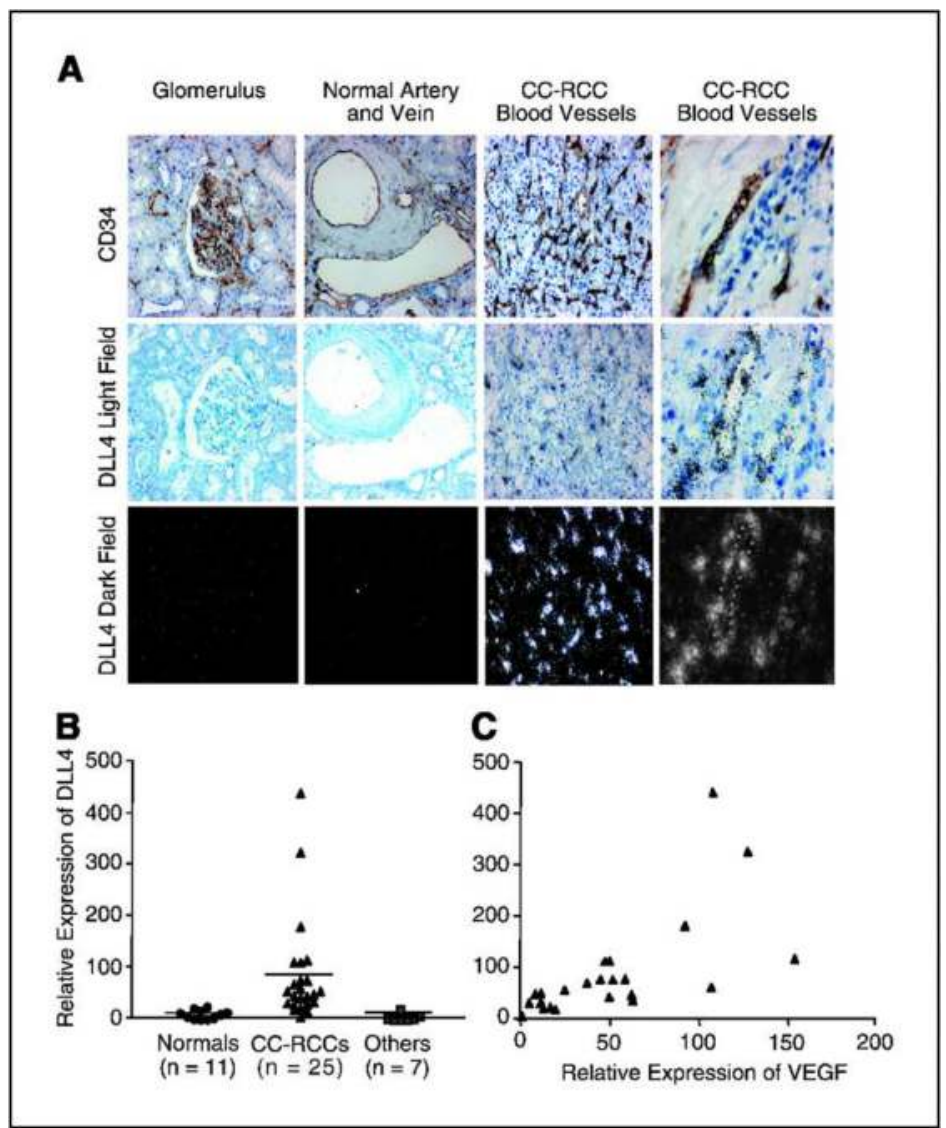

Fig. 1. Differential expression of DLL4 in renal cancer.

In situ analysis (A) or RT-PCR (B) demonstrates higher relative expression (up to nine-fold) of human DLL4 in CC-RCC samples compared to normal kidney tissue. (C) DLL4 expression correlates with elevated VEGF-A expression. (CAdapted and reprinted by permission from the American Association for Cancer Research: Patel et al, Up-regulation of delta-like 4 ligand in human tumor vasculature and the role of basal expression in endothelial cell function, Cancer Res, 2005, (19) 65: 8692.

non-viable due to severe vascular defects and impaired somitogenesis with extensive cell death resulting in lethality by embryonic day 9.5 (Conlon et al., 1995) -10.5 with complete resorption by d11.5 (Swiatek et al., 1994). Endothelial cell specific deletion of NOTCH1 has a similar phenotype, demonstrating the critical endothelial compartment function of NOTCH1 in early vascular development (Limbourg et al., 2005). While the NOTCH4 knockout mouse is viable, compound loss of NOTCH1 and NOTCH4 shows a more profound vascular phenotype than deletion of either single gene alone (Krebs et al., 2000), suggesting a possible NOTCH1 redundancy for NOTCH4 in development.

$\mathrm{NOTCH} 2$ is also expressed in the mouse vasculature, most notably in the developing heart (Loomes et al., 2002). However, mice expressing a NOTCH2 deletion mutant that lacks all but 
one of the ankyrin repeats in the N2ICD die prior to NOTCH2 heart expression at $\mathrm{d} 11.5$ with abnormalities observed in the neuroepithelium and cranial ganglia cells, as well as the optic and otic vesicles (Hamada et al., 1999). A NOTCH2 hypomorph allele causes perinatal lethality due to defects in the glomerular development in the kidney (McCright et al., 2001). Taken together, these data suggest that $\mathrm{NOTCH} 2$ may have non-vascular roles in development.

Despite expression of NOTCH3 in the mouse heart (Loomes et al., 2002), NOTCH3 null mice are viable, fertile and show no overt phenotype either alone, and unlike NOTCH4, does not show increased vascular defects on a NOTCH1 null background (Krebs et al., 2003). A detailed analysis of the NOTCH3 phenotype indicates that this receptor may play a role in arterial identity of vascular smooth muscle cells, as distal arteries exhibit structural lesions and defective arterial myogenic responses (Domenga et al., 2004). In humans, NOTCH3 mutations are associated with Cerebral Autosomal Dominant Arteriopathy with Subcortical Infarcts and Leukoencephalopathy (CADASIL), an adult onset vascular disorder caused by systemic vascular lesions that result in a myriad of symptoms, including recurrent ischemic strokes (Joutel et al., 1996). These mutations do not seem to affect ligand/receptor interaction nor do they disrupt subsequent signaling (Haritunians et al., 2002). The mutations allow accumulation of a soluble NOTCH3 ECD (Joutel et al., 2000), and this could locally interfere with signaling of multiple intact $\mathrm{NOTCH}$ receptors and their ligands as there is substantial binding promiscuity among $\mathrm{NOTCH}$ receptors and ligands.

\subsection{Functional role of NOTCH ligands in developmental angiogenesis}

Knockout of JAG1 in the mouse results in embryonic lethality by E10 -10.5 and can be identified by hemorrhage and the lack of large blood vessels in the yolk sac, reminiscent of the NOTCH1 null phenotype. Additional vascular defects and hemorrhage are also present in the cranial area and there is an overall loss of vessel branching and reduced vessel diameter (Xue et al., 1999). Like the NOTCH1 deletion, the phenotype is similar when the knockout is restricted to the endothelial cell compartment suggesting that the early lethality is due to JAG1 expression in the vasculature (High et al., 2008). Detailed examination shows that vascular smooth muscle cell (VSMC) markers are severely diminished despite intact NOTCH signaling in the endothelial cells themselves. The primary role of JAG1 may therefore be to signal to the VSMC, and other ligands may be able to compensate for the loss of JAG1-triggered signaling in the endothelial cells. Other studies using conditional loss or overexpression of JAG1 suggest that JAG1 plays a proangiogenic role in the presence of other ligands in the developing retina and can act as a partial antagonist to DLL4 to modulate NOTCH pathway signaling (Benedito et al., 2009). In humans, JAG1 mutations have been associated with Allagille syndrome (AGS), which has a variety of symptoms including reduced numbers of intrahepatic bile ducts, cardiac defects (including pulmonary artery stenosis and hypoplasia, pulmonic valve stenosis and tetralogy of Fallot), skeletal defects, ophthalmological abnormalities, renal and pancreatic abnormalities, and intracranial bleeding. Although mutations in NOTCH2 have not been associated with AGS, combined mutations of both NOTCH2 and JAG1 best recapitulate the human pathology of AGS in the mouse (McCright et al., 2002).

DLL4 is expressed throughout the vascular endothelium, most notably in the endothelial cells of actively growing capillaries at the leading front of the superficial vascular plexus, while mature capillaries have lower levels of DLL4 expression as analyzed in situ (Shutter et al., 2000) or by reporter construct (Lobov et al., 2007). Over time, DLL4 expression decreases in mature veins but increases in the arteries. DLL4 inactivation results in an early lethality 
and haploinsufficiency by E9.5 in some mouse strains. DLL4 knockout embryos exhibit an avascular yolk sac, arterio-venous malformations (AVMs), growth retardation, and an overall lack of major arteries and vascular remodeling (Krebs et al., 2004) In rare cases of heterozygote survival, defects are also observed in the developing retina characterized by enhanced angiogenic sprouting and endothelial cell proliferation, which is a hallmark of a DLL4 blockade (Lobov et al., 2007).

Delta-like 1(DLL1) has been reported to be expressed in the endothelium of the developing embryo in both arteries and veins (Beckers et al., 1999). DLL1 is detectable in fetal arterial endothelial cells beginning at embryonic day 13.5, and is a critical regulator of arterial identity. Disruption of DLL1 leads to lethality by E12 with aberrant somite compartmentalization and hemorrhagic events (Hrabe de Angelis et al., 1997). Loss of DLL1 in the mouse also leads to a downregulation of VEGF receptor 2 (VEGFR2) and neuropilin (NRP) expression as well as a reduction in the levels of activated NOTCH1 receptor, despite the expression of DLL4 and JAG1 in the endothelium (Sorensen et al., 2009). The role of DLL1 is not restricted to the developing embryo, as heterozygous adult mice display impaired arteriogenesis after induction by ischemia (Limbourg et al., 2007).

Knockout of the Jagged2 (JAG2) gene in mouse die at birth due to cleft palate and lack observable defects in the vascualture. Future studies using a conditional allele may illuminate a role of JAG2 in the vasculature of the adult mouse (Xu et al., 2010). A targeted Delta-like 3 (DLL3) knockout mouse is viable, but homozygous mutants have growth defects with disorganized vertebrae and costal defects resulting from defective segmentation in the embryo and delayed and irregular somite formation. Similarly, two viable spontaneous mutations of DLL3, pudgy and omagari, have abnormal formation and patterning of somites. Although clearly important for normal development, neither the JAG2 nor the DLL3 null mice have apparent signs of an angiogenic defect. However, this does not exclude a vascular role beyond their essential functions in development.

\subsection{Overview of NOTCH signaling}

The four NOTCH receptors are single pass transmembrane proteins with a large number (25-29) of epidermal growth factor-like (EGF-like) motifs that are repeated throughout their extracellular domains (ECD) (see Kopan and Ilagan, 2009 for a recent comprehensive review). They are each synthesized as a proreceptor before cleavage by a furin-like protease during their transport to the surface (Blaumueller et al., 1997; Logeat et al., 1998). The ECDs of $\mathrm{NOTCH}$ receptors also contain $3 \mathrm{LIN12/NOTCH}$ repeat (LNR) domains that are noncovalently linked to the rest of the receptor through a heterodimerization (HD) domain. The HD and LNR domains collectively make up the negative regulatory region (NRR), which overall prevents activation of the receptor in its non-ligand bound state (SanchezIrizarry et al., 2004).

The classical NOTCH ligands are also single pass transmembrane proteins. (Figure 2) The ligands have multiple EGF repeats as well as a Delta, Serrate, and Lag-z (DSL) domain that is essential for interaction with the $\mathrm{NOTCH}$ receptors. Jagged ligands distinguish themselves from the Delta-like ligands by an additional cysteine rich domain (reviewed by Kopan, 2009). There are also non-classical ligands that can activate $\mathrm{NOTCH}$ receptors in specific contexts, such as the Delta/NOTCH-like EGF-related receptor (DNER), which acts as a NOTCH ligand in neurons for glial cell differentiation (Eiraku et al., 2005) or F3/cortactin, which is involved in $\mathrm{NOTCH}$ activation during oligodendrocyte maturation (Hu et al., 2003). Ligands and receptors are proposed to be expressed on opposing cells and 
A

Jagged1, 2

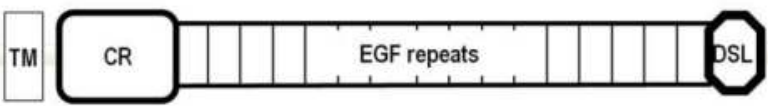

田

DII1, 4

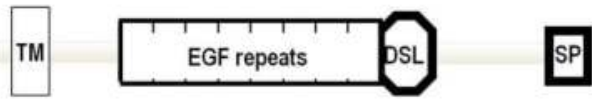

DII3

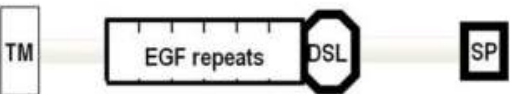

B
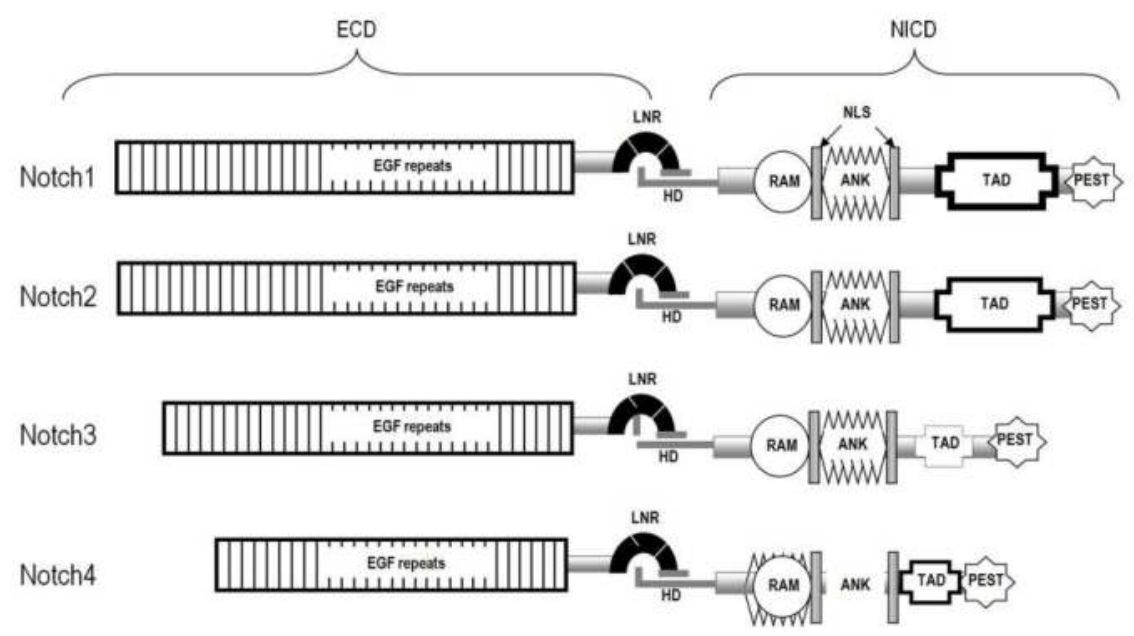

Fig. 2. Diagram of the NOTCH ligands and receptors.

A. The NOTCH ligand family has five distinct transmembrane ligands, each encoded by its own gene. The extracellular domains of all the receptors contain a signal peptide (SP), multiple EGF repeats, and a Delta/Serrate/Lag-2 (DSL) as well as a transmembrane (TM) domain. The Jagged ligands also have a cysteine rich domain. All ligands have a small intracellular domain as well. B. The NOTCH receptor family has four distinct transmembrane receptors, each encoded by its own gene. The extracellular domains of all the receptors contain multiple EGF repeats as well as an LNR domain which protects the receptors from cleavage and thereby preventing activation. Ligand binding is thought to be mediated by EGF repeats 11-13. The intracellular domains contain a RAM domain, six ANK repeats, two NLS sequences, and a PEST domain to regulate the stability of the protein. NOTCH3 has a weak transcriptional activation domain (TAD) compared to other receptor family members. 
operate as a short-range signaling system. When a NOTCH ligand binds to a NOTCH receptor, the interaction induces a conformational change in the NRR region allowing exposure of additional cleavage sites (reviewed in Gordon et al., 2008). The first cleavage is mediated by ADAM-type metalloproteases on the ECD side of the protein (Gordon et al., 2007). Nicastrin, a transmembrane glycoprotein protein in the presenilin $/ \gamma$-secretase protease complex, helps mediate the second cleavage by docking $\mathrm{NOTCH}$ into the protease (Chen et al., 2001), resulting in the release of the NOTCH intracellular domain (NICD) (Struhl and Greenwald, 1999). The NICD contains a nuclear localization signal (NLS) that regulates translocation into the nucleus (Figure 3) (Schroeter et al., 1998).

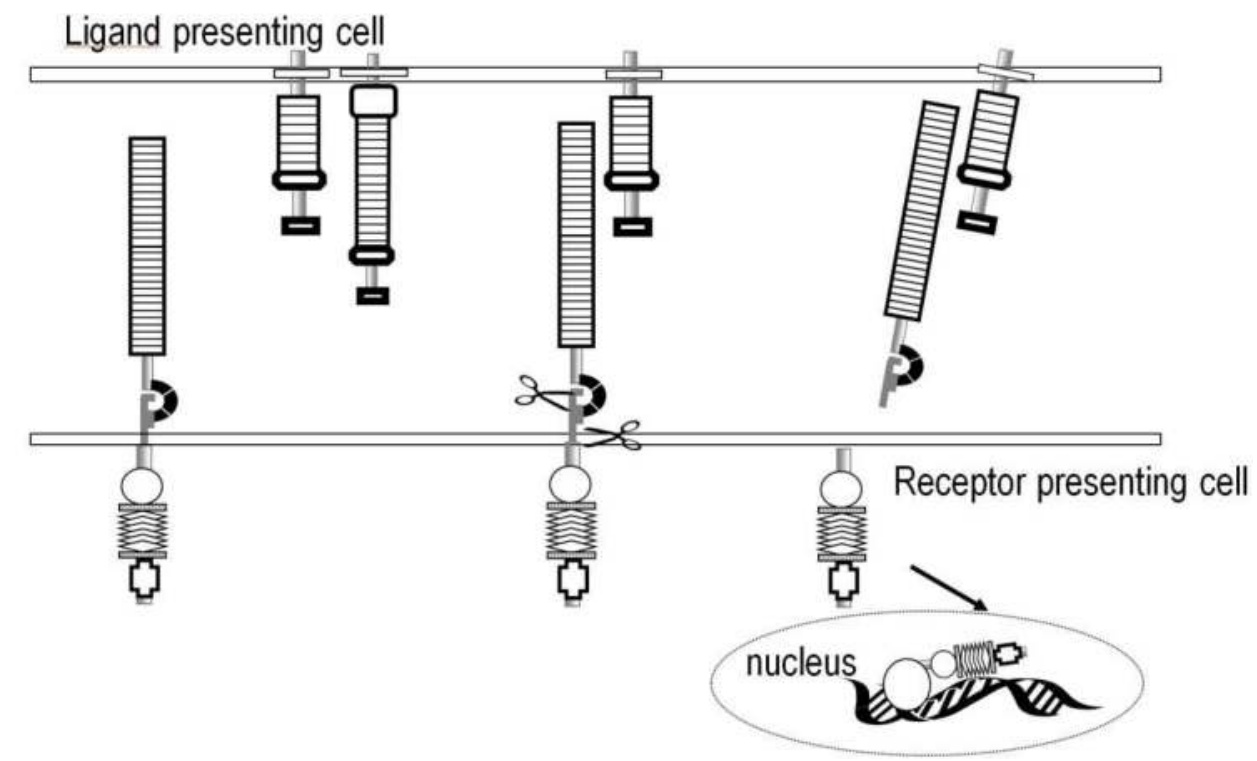

Fig. 3. Canonical NOTCH receptor signaling.

Ligand presentation by an adjacent cell can activate the receptor by promoting two sequential cleavages (denoted by scissors) by the TACE family of proteases and $\gamma$-secretase. These cleavages liberate the NOTCH receptor intracellular domain and allow it to translocate to the nucleus. NICD then interacts with the CSL family of transcription factors and induces expression of $\mathrm{NOTCH}$ target genes.

The NICD of all four NOTCH receptors contains a regulation of amino acid (RAM) domain, ankyrin (ANK) repeats, a nuclear localization signal (NLS) (Lieber et al., 1993), and a proline, glutamate, serine, threonine (PEST) domain (Figure 2). Cdk8 directly phosphorylates the PEST domain in all NICDs, which then become substrates for the nuclear ubiquitin ligase Sel10, regulating NICD turnover. (Fryer et al., 2002; Fryer et al., 2004; Oberg et al., 2001). Prior to destruction, the NICD interacts via its ANK repeats with the DNA binding protein $\underline{C B F 1 / D r o s o p h i l a ~} \underline{\mathrm{Su}}(\mathrm{H}) / \mathrm{C}$.Elegans LAG-1 (CSL), which, in the absence of NOTCH, associates with co-repressors and histone deacetylases to prevent transcription of key gene targets (Jarriault et al., 1995). Once NICD is present and binds to CSL, the co-repressors are displaced allowing recruitment of mastermind (MAML) and conversion into a transcriptional activation complex. The co-regulator SKIP and histone 
deacetylase p300 are also recruited to the same promoters (Wallberg et al., 2002; Zhou et al., 2000). This allows the transcription of members of the Hes and Hey family of transcriptional repressors (Ohtsuka et al., 1999), reviewed in (Iso et al., 2003). The strength of the transcriptional signal varies among family members and seems to depend upon cofactor association as well as binding site orientation (Ong et al., 2006).

NOTCH signaling between receptors and ligands can be further regulated by posttranslational glycosylation of the receptors and ligands which contain multiple potential sites for $\mathrm{N}$ - and $\mathrm{O}$ - linked glycosylation. The Fringe family of glycosyltransferases can mediate O-fucose elongation on the NOTCH ECD (Moloney et al., 2000) thereby changing affinity of NOTCH receptors for their ligands. For example Fringe modification of NOTCH1 increases activation by Delta1 but decreases activation by JAG1 (Yang et al., 2005). Dynamic fringe family expression can thereby substantially modify NOTCH signaling (reviewed by (Haines and Irvine, 2003). Rumi has also been identified in Drosophilla as an enzyme that can add O-glucose to the NOTCH ECD and may affect NOTCH signaling by enhancing cleavage and activation of NOTCH by its ligands (Acar et al., 2008).

\subsection{Preclinical data using pharmacological inhibitors targeting NOTCH signaling}

The genetic data ascribing a key role for $\mathrm{NOTCH}$ signaling in angiogenesis has encouraged multiple groups to create molecules to specifically inhibit NOTCH signaling and evaluate their subsequent effects on the tumor vasculature. Such agents include soluble DLL4 (SolDLL4) fused to Fc and neutralizing antibodies specific to DLL4 or NOTCH1 that inhibit the receptor/ligand interaction (Funahashi et al., 2008; Noguera-Troise et al., 2006; Ridgway et al., 2006; Wu et al., 2010). These agents have demonstrated an anti-tumor effect in a broad spectrum of xenograft models, including those with intrinsic or acquired resistance to VEGF therapy. Examination of the tumor vasculature with all agents revealed an increase in sprouting leading to an overall expansion of non-productive vasculature, as evidenced by greater hypoxia in the tumor itself and decreased perfusion of these new vessels. Subsequent studies using live-cell imaging suggest that the aberrant sprouting is due to the fact that tip cell positioning is dynamic and migration of vessel stalk cells creates competition for the tip position among ECs. Regulation and organization of the vessel is determined by DLL4 expression, via modulation by VEGF receptor 1 and 2 (VEGFR1 and VEGFR2) levels, to allow tip formation only towards the highest concentrations of VEGF-A. Disruption of DLL4/NOTCH signaling using pharmacological inhibitors subsequently disrupts the ability of the vessel to organize (Jakobsson et al., 2010).

Blockade of DLL4 signaling has been reported to be enhanced with blockade of other angiogenic signaling pathways. Notably, the efficacy of anti-DLL4 treatment was increased upon the addition of agents designed to inhibit VEGF signaling, either with an anti-VEGF-A antibody (Ridgway et al., 2006), or a soluble VEGFR2-Fc fusion protein (Noguera-Troise et al., 2006). As bevacizumab is already an approved agent for human use, there is clear potential for use as a clinical combination. A recent study has also demonstrated that inhibition of EphrinB4 signaling by a soluble EphB4 albumin fusion protein in combination with either allelic deletion or a soluble DLL4-Fc fusion construct could also enhance efficacy in the RipTag model, a highly angiogenic model of pancreatic islet carcinogenesis (Djokovic et al., 2010).

\subsection{Potential preclinical toxicities associated with chronic NOTCH signaling inhibition}

Although these data suggest that NOTCH signaling is an attractive target for therapeutic intervention in tumor angiogenesis, there may be substantial side effects associated with short 
and long term blockade of NOTCH signaling. Several studies suggest that NOTCH signaling acts as a tumor suppressor in specific tissues. For example, skin specific ablation of NOTCH1 results in hyperproliferation of the basal epidermal layer in young mice and epidermal and corneal hyperplasia in older mice (Nicolas et al., 2003). A recent study has also demonstrated that NOTCH1 can act as a tumor suppressor in a K-Ras driven model of pancreatic cancer. Pancreas specific K-RasG12D expression causes early stage lesions of pancreatic cancer, reminiscent of ADM/Tc, PanIN1A or PanIN1B stages in human disease (Hingorani et al., 2003). Pancreas specific NOTCH loss in this background significantly accelerates pancreatic lesions and produced a more advanced grade (PanIN1B to PanIN2), suggesting that loss of NOTCH results in increased tumor incidence and progression (Hanlon et al., 2010). In both cases, increased proliferation was observed as assessed by Ki67 staining of affected tissue. $\mathrm{NOTCH}$ signaling may also have a tumor suppression role in myeloid leukemia due to altered fate specification. Deletion of NOTCH1 and NOTCH2 or Nicastrin results in a murine form of chronic myelomonocytic leukemia (CMML) due to accumulation of granulocyte/monocyte progenitors. Loss of NOTCH dependent inhibition of genes that specify myelomonocytic fate for the blood cells causes resultant pathology. Interestingly, mutations in NOTCH signaling were found in 5/42 patient samples with CMML (Klinakis et al., 2011) suggesting that this may be relevant to the development of human disease.

Another intriguing genetic study that demonstrated the effects of long term NOTCH loss used a model in which the endogenous NOTCH1 gene was replaced with NOTCH1-Cre fusion protein (Vooijs et al., 2007). When crossed with a mouse containing a floxed NOTCH1 allele, it allows progressive inactivation of NOTCH1 dependent signaling in its physiologic context, i.e. as NOTCH1 is activated, it is lost. Beyond a broad effect on overall survival due to hemorrhage and vascular tumors, 11 out of 13 mice in this system demonstrated aberrations in multiple organs, including the liver, ovary, testis, skin, lymph nodes, uterus, and colon. The liver in particular, was the organ most affected by NOTCH1 activated loss and had evidence of hemangiomas and proliferation specifically associated with NOTCH1 loss (Liu et al., 2011).

In other preclinical studies, pharmacological agents causing long term blockade, such as an anti-DLL4 antibody, also caused unexpected proliferative effects in select tissues (Yan et al., 2010). Dose dependent ulcerating subcutaneous tumors (mouse) as well as sinusoidal dilation and centrilobular hepatocyte atrophy in the liver (mouse, rat, monkey) was observed. It was also noted that similar liver effects were seen with both an anti-NOTCH1 antibody and a $\gamma$-secretase inhibitor, which would inhibit processing or activation of all $\mathrm{NOTCH}$ recetpors, suggesting that the effects were likely pathway associated. However, impact on overall survival was not observed as was seen in the genetic study, possibly due to shorter exposure as compared to genetic loss. It is unknown if the other vascular beds that were described to be affected in the genetic study were affected by antibody inhibition as they were not discussed. Interestingly, there may be mechanisms to counteract NOTCH signaling induced proliferation. For example, hepatic lesions caused by DLL4 inhibition were prevented when combined with systemic Ephrin B2/EphB4 inhibition, (Djokovic et al., 2010). As mentioned earlier, this combination enhanced anti-DLL4 efficacy, and that combination therapy may be a possible approach to mitigate $\mathrm{NOTCH}$ pathway associated toxicities while preserving anti-tumor effects.

\subsection{Clinical perspectives}

Despite the possible toxicities described above, the compelling preclinical efficacy data generated with neutralizing agents to DLL4 and NOTCH1 have encouraged efforts to 
evaluate these agents in the clinic. Currently two companies have active clinical trials that target DLL4 (www.clinicaltrials.gov). OMP-21M18 (Oncomed Pharmaceuticals) is a neutralizing anti-DLL4 mAb that is currently in Phase 1 and $1 \mathrm{~b}$ clinical trials in combination with chemotherapy. OMP-21M18 is specific for human DLL4, and preclinical data with this antibody demonstrates a direct anti-tumor effect for primary human xenografts that express huDLL4. However, OMP-21M18 combined with an antibody that recognizes muDLL4 demonstrated increased efficacy, suggesting that DLL4 signaling has a role in both tumor and stroma in primary human xenograft growth (Hoey, 2009). A second human anti-DLL4 $\mathrm{mAb}$, REGN-421, created by Regeneron pharmaceuticals, is also in Phase 1 clinical trials. Given the preclinical data, there may be benefit to combination of an agent targeting DLL4 with bevacizumab. A recent retrospective analysis demonstrates that DLL4 expression, along with VEGF-C and neuropilin-1, indicated a poor response to bevacizumab treatment and may be a path of resistance in human disease (Jubb et al., 2011).

\section{Function of ALK1 / Endoglin signaling in angiogenesis}

A second angiogenic signaling axis with potential for therapeutic intervention is the ALK1/Endoglin pathway. In recent years, therapeutics directed at the ALK1/Endoglin signaling axis have entered phase 1 and 2 clinical trials, marking a clinical transition for a field of research dating back more than 20 years with the cloning of Endoglin (ENG or CD105) and ALK1 (Attisano et al., 1993; Gougos and Letarte, 1990). ENG, a homo-dimeric membrane glycoprotein highly expressed in endothelial cells (Gougos and Letarte, 1988), has homology to betaglycan and is capable of binding several cytokines of the TGF $\beta$ super family, leading to its classification as a Type III TGF $\beta$ co-receptor. ALK1, the product of the Activin receptor-like kinase 1 gene (ACVRL1), is an endothelial-specific serine/threonine kinase belonging to the Type I TGF $\beta$ receptor family (Attisano et al., 1993). Together, ENG and ALK1 define a signaling receptor complex for the BMP9 and BMP10 cytokines at the surface of endothelial cells. ENG and ALK1 are required for angiogenesis and vascular morphogenesis and anti-ENG and anti-ALK1 targeted agents have the potential to disrupt tumor angiogenesis independently or cooperatively with anti-VEGF treatment.

\subsection{Normal and tumor endothelial expression of ENG and ALK1}

ENG and ALK1 are both preferentially expressed in endothelial cells. During development, ENG and ALK1 present very similar expression patterns in areas of vasculogenesis (yolk sac, early embryonic vasculature) and angiogenesis (throughout the late embryonic vascular endothelium) (Jonker and Arthur, 2002; Roelen et al., 1997; Seki et al., 2003). ENG is detected in veins, liver sinusoidal endothelial cells and arteries, while ALK1 is only detected in developing arteries, suggesting a role in arterial differentiation (Jonker and Arthur, 2002; Seki et al., 2003). In the adult, both transcripts are weakly detected in the microvasculature of several organs including the lung (Miller et al., 1999; Panchenko et al., 1996; Seki et al., 2003) but the ENG protein is readily detected in the liver and kidney microvasculature (Minhajat et al., 2006). ENG protein expression is elevated in endothelial cells when angiogenesis is activated during wound repair and chronic inflammation (Torsney et al., 2002). Protein expression of ENG and ALK1 is induced in the endothelium of nearly all solid tumors (Burrows et al., 1995; Hu-Lowe et al., 2011; Miller et al., 1999; Minhajat et al., 2006; 
Wang et al., 1993) (Fig. 4). ENG is also detected in cell types other than endothelial cells, such as activated monocytes and at the surface of cancer cells in melanoma and leukemia (Altomonte et al., 1996; Fonsatti et al., 2001; Gougos and Letarte, 1988), while ALK1 is also detected in mesenchymal cells of multiple organs and in trophoblast giant cells during embryogenesis (Roelen et al., 1997).
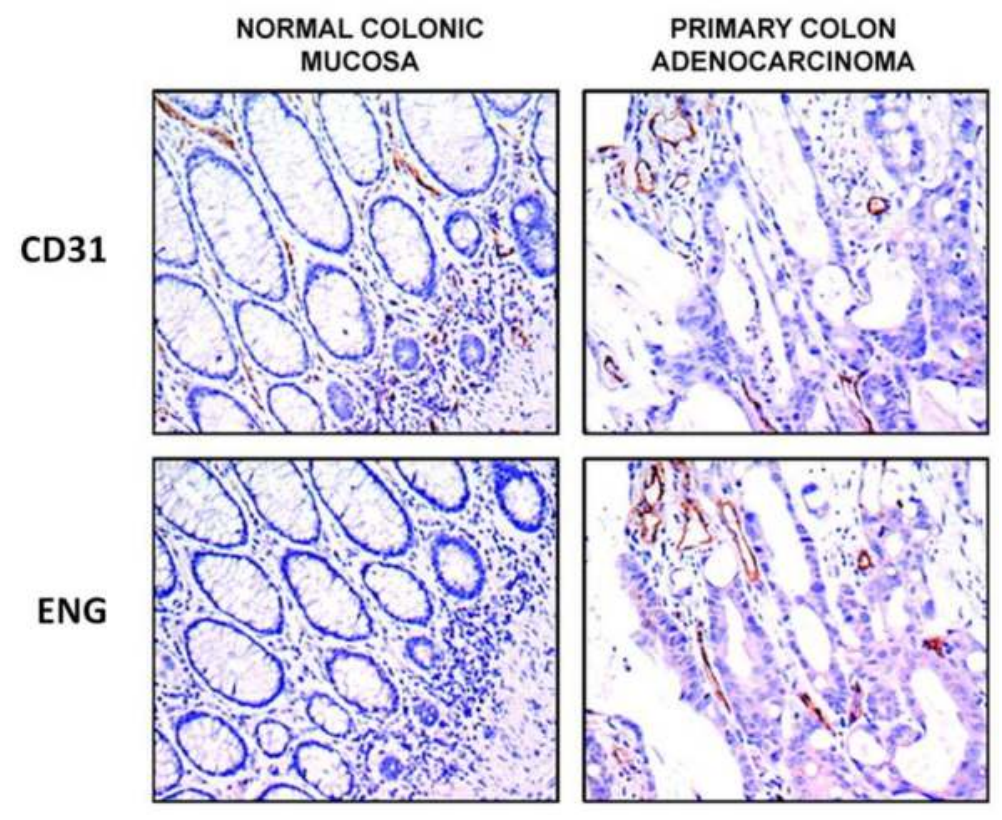

Fig. 4. Differential expression of ENG in tumor endothelial cells.

In contrast to CD31 staining, an endothelial cell marker detected in both the normal colonic mucosa and in the vasculature of colon tumors, ENG is detected at much higher levels in the tumor vasculature and not in the normal colonic vasculature (Dallas et al., 2008). (CAdapted and reprinted by permission from the American Association for Cancer Research: Dallas et al, Endoglin (CD105): A marker of tumor vasculature and potential target for therapy, Clin Cancer Res, 2008, 14(7): 1933.

The relative specificity of ENG and ALK1 expression in endothelial cells and their induction in cancer-associated endothelial cells stem from several mechanisms. First, ENG and ALK1 share a combination of transcription factor binding sites with other endothelial-specific genes such as PECAM1 and VEGFR2 representing a possible endothelium transcriptional code (Garrido-Martin et al., 2010). Second, ENG is a HIF-1 $\alpha$ target gene induced by hypoxia, (Li et al., 2003; Sanchez-Elsner et al., 2002), a near universal hallmark of cancer (Hanahan and Weinberg, 2011), and the ALK1 promoter contains several HIF-1 $\alpha$ binding motifs (Garrido-Martin et al., 2010). Third, ALK1 is induced by BMP4 (Shao et al., 2009), a cytokine required for vascular development (David et al., 2009). Finally, ENG transcription is induced by TGF $\beta$ (Sanchez-Elsner et al., 2002) and BMP9 signaling (David et al., 2007) through numerous SMAD-binding elements in the ENG promoter. 


\subsection{Hemorrhagic Hereditary Telangectasia: a vascular genetic disorder linked to ENG and $A L K 1$ loss-of-function}

Hemorrhagic Hereditary Telangectasia (HHT) is a rare autosomal dominant genetic disorder characterized by vascular abnormalities in the skin, brain, lung, liver and gastrointestinal tract resulting in the dilatation of post-capillary venules, disappearance of capillary beds, and AVMs (Fig. 5 A-B) (Lebrin and Mummery, 2008). Affected individuals suffer benign skin and mucosal dilatations (telangectasia), nosebleeds and more severe hemorrhage in affected organs (Guttmacher et al., 1995). Most subjects affected with HHT have been linked to heterozygous mutations in ENG (McAllister et al., 1994) or ALK1 (Johnson et al., 1996) and are classified as HHT1 or HHT2 respectively. In most cases of HHT1, mutations generate null alleles of ENG leading to reduced expression of the ENG coreceptor, indicating that haploinsufficiency is the underlying genetic mechanism of disease (Fernandez et al., 2005; Pece-Barbara et al., 1999). For HHT2, the affected ALK1 allele usually contains missense point mutations in the ALK1 kinase domain. The majority of these mutations lead to normal expression of ALK1 but to an absence of signal transduction from the BMP9 cytokine (Ricard et al., 2010) (see Signaling section 3.3). Thus mechanistically, HHT2 is likely caused by ALK1 haploinsufficiency.

Mouse models carrying heterozygous genetic deletions of ENG or ALK1 genes recapitulate the haploinsufficient pathological features of HHT such as telangectasias and AVMs (Bourdeau et al., 1999; Srinivasan et al., 2003; Torsney et al., 2003). In ENG or ALK1 homozygous mutant embryos, embryonic and yolk sac vascular development proceed normally until day E8.5 (Li et al., 1999; Urness et al., 2000). Hence, neither gene is required for vasculogenesis, the process of endothelial cell differentiation from mesodermal precursors, their assembly into primitive vascular networks and the coalescence of angioblasts to form the endothelial tubes of the dorsal aorta and the cardinal vein (Arthur et al., 2000; Bourdeau et al., 1999; Li et al., 1999; Urness et al., 2000). However, between E9.0 and E9.5, abnormal vascular shunts reminiscent of AVMs appear in both ALK1 and ENG mutant embryos, connecting the dorsal aorta and the cardinal vein and causing blood flow shunts in the embryo (Fig. 5C) (Li et al., 1999; Sorensen et al., 2003; Urness et al., 2000). The maturation of the primitive endothelial network of the yolk sac through angiogenesis also fails to occur in ENG or ALK1 mutant embryos, leading to the disappearance of the vitelline vasculature in both genotypes by E10.5 (Li et al., 1999; Urness et al., 2000). ENG and ALK1 mutant embryos also present severe defects in heart development as both genes are required for heart valve formation (Arthur et al., 2000; Bourdeau et al., 1999). The angiogenesis defects appear to be primary defects and not secondary heart phenotype defects, since the vascular malformations in ENG and ALK1 mutant embryos occur before the onset of heart development phenotypes (Sorensen et al., 2003).

Angiogenesis defects in ALK1 and ENG mutant embryos result from the failure of endothelial cell reorganization leading to abnormal vessel shunting, but also from profound defects in perivascular smooth muscle cells (VSMC) and pericyte recruitment around endothelial cells, leading to vessel fragility and hemorrhaging (Li et al., 1999; Torsney et al., 2003; Urness et al., 2000). Thus, both genes are required for two defining aspects of angiogenesis: endothelial network remodeling and vascular morphogenesis through recruitment of pericytes (Risau, 1997), essential support cells for the formation and maintenance of the vasculature (Bergers and Song, 2005). 

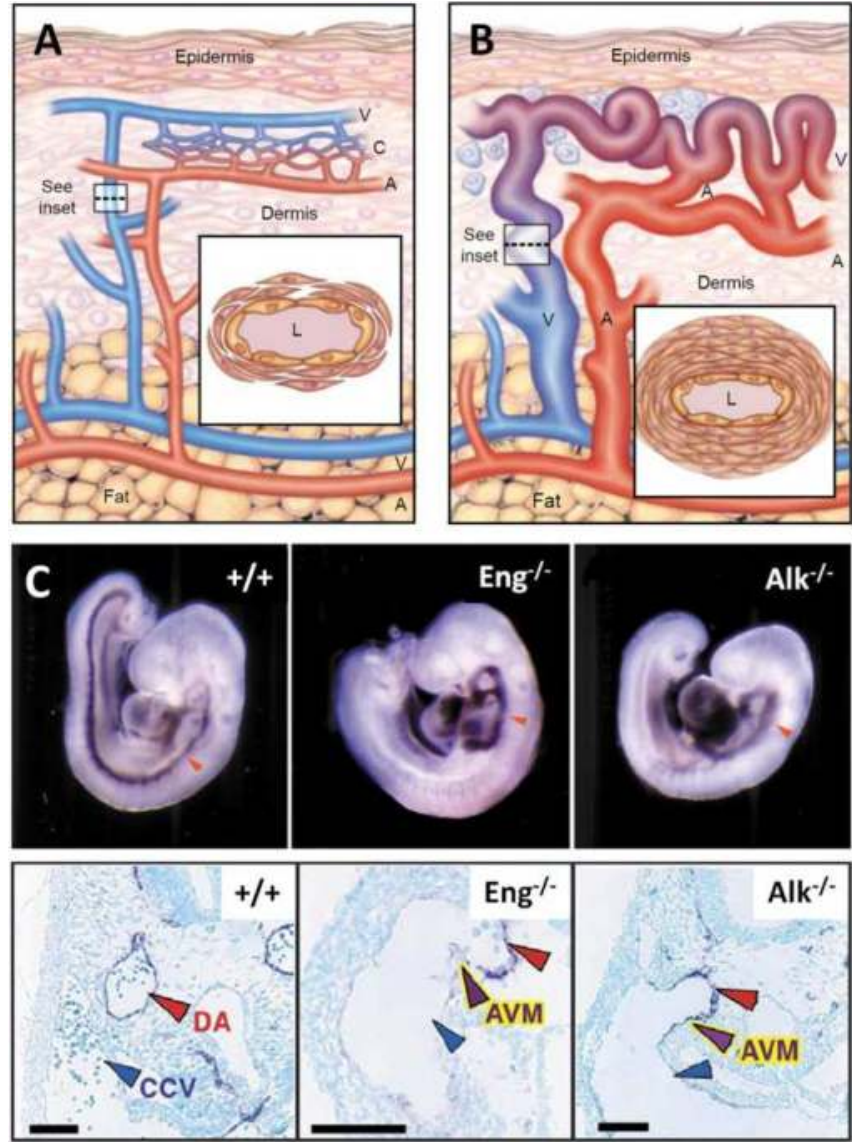

Fig. 5. Phenotypic consequences of loss of ENG or ALK1 function.

A. Normal dermal vasculature: well-differentiated veins and arteries are separated by micro-vascular capillary beds. B. Hereditary Hemorrhagic Telangectasia (HHT) subjects present with enlarged vessels, disappearance of micro-vascular capillary beds and arterioveinous malformations (AVM) leading to hemorrhage (Guttmacher et al., 1995). C. Mouse embryos carrying ENG or ALK1 mutations present similar defects: shunting of the circulation (upper panels), due to the fusion between the dorsal artery (DA) and the cardinal vein (CCV) (lower panels) (Sorensen et al., 2003). (C) Adapted and reprinted by permission from the Massachusetts Medical Society: Guttmacher et al, 1995 Hereditary Hemorraghic Telangectasia, NEJM, 1995, (333) 14: 919, and from Elsevier: Sorensen et al, 2003, Loss of distinct arterial and venous boundaries in mice lacking Endoglin, Dev Biol 261: 236-7.

\subsection{Signal transduction through ALK1 and ENG}

Several alternative models have been proposed regarding the identity of the cytokine capable of triggering physiological ALK1/ENG signaling in endothelial cells, and the type of SMAD response these cytokines trigger. In the following sections, we will review these models and explain why we favor the BMP9/ALK1/ENG/SMAD1-5 signaling model. 


\subsection{1 "Cross-over" TGF $\beta /$ SMAD1-5 signaling model}

Initial studies describing ENG and ALK1 indicated that the two proteins could be part of a TGF $\beta$ receptor complex. Over-expressed ENG and ALK1 were found in protein complexes with TGF $\beta$ receptor 2 (TBR2) and radio-labeled TGF $\beta 1$ (Attisano et al., 1993; Cheifetz et al., 1992) and endogenous complexes containing ENG, TBR2 and radio-labeled TGF $\beta 1$ were found in primary endothelial cells (Cheifetz et al., 1992; Yamashita et al., 1994). The finding that TGF $\beta$ could induce SMAD1-5 phosphorylation in Mouse Embryonic Endothelial Cells (MEEC) and Bovine Aortic Endothelial Cells (BAEC) through a signaling complex containing ENG, ALK1, ALK5 and TBR2 led to a model of "cross-over" TGF $\beta$ signaling, whereby TGF $\beta$ / ALK1 signaling antagonized TGF $\beta$ / ALK5 signaling in endothelial cells (Fig. 6A) (Goumans et al., 2003; Goumans et al., 2002; Lebrin et al., 2004; Oh et al., 2000). These results were unexpected since TGF $\beta$ was thought to be incapable of signaling through BMP Type I receptors such as ALK1. Until then, the "canonical" model of TGF $\beta$ signaling axis postulated that ALK5 was the only Type I receptor for TGF $\beta$ and that TGF $\beta$ exclusively signaled via phosphorylation of SMAD2-3 (Massague, 2000) (Fig. 6B). Several subsequent studies have shown that immortalized or transformed cells could display a non-canonical "cross-over" TGF $\beta$ signaling pathway leading to SMAD1-5 phosphorylation via BMP Type I receptors (Daly et al., 2008; Finnson et al., 2008; Liu et al., 2009). This transition to "crossover" TGF $\beta / S M A D 1-5$ signaling from "canonical" TGF $\beta / S M A D 2-3$ signaling could explain how cancer cells switch from an anti-proliferative to a pro-invasive TGF $\beta$ response in the course of malignant cellular transformation (Liu et al., 2009).

Thus, while there is no doubt that "cross-over" TGF $\beta /$ SMAD1-5 signaling has been detected in a number of immortalized and transformed cell lines and in some mesenchymal cell types (Wrighton et al., 2009), the evidence for such a signaling axis existing in endothelial cells rested entirely on results obtained in MEEC and BAEC (Goumans et al., 2002). However, given that MEEC cells are immortalized through infection with a retrovirus encoding the polyoma middle $\mathrm{T}$ oncoprotein (Larsson et al., 2001), it is unlikely that they represent a normal and physiological endothelial cell type. In addition, the observation that primary endothelial BAEC cells exhibit TGF $\beta /$ SMAD1-5 signaling (Goumans et al., 2002) could not be reproduced (Scharpfenecker et al., 2007; Shao et al., 2009) and TGF $\beta / S M A D 1-5$ signaling could not be detected in primary human endothelial cells (David et al., 2007; Shao et al., 2009), suggesting that the "cross-over" TGF $\beta /$ SMAD1-5 signaling axis may only be detected in immortalized endothelial cell types.

In vivo evidence also cast doubt on the proposed model of TGF $\beta$ as the key cytokine functioning upstream of ALK1/ENG/SMAD1-5 signaling in endothelial cells. Initially, because ALK1, ALK5, ENG and TBR2 mutant embryos all demonstrated severe vascular phenotypes at day 10.5, including disappearance of the yolk sac vasculature, speculation that they were possibly engaged in the same signaling axis emerged (ten Dijke and Arthur, 2007). However, using genetically engineered mouse strains carrying the LacZ reporter gene under the control of the endogenous $A L K 1$ or $A L K 5$ promoters, Seki and colleagues demonstrated that $A L K 1$ was expressed in endothelial cells, whereas $A L K 5$ was expressed in VSMC (Seki et al., 2006), suggesting distinct in vivo functions of the two receptors in vascular development. Moreover, endothelium-specific genetic deletion of ALK1 during embryogenesis triggered severe vascular defects mimicking pathological features of HHT, whereas endothelium-specific deletion of TBR2 and ALK5, the two main receptors for TGF $\beta$, presented no detectable phenotype in the developing vasculature (Park et al., 2008). These 
results suggest that the function of ALK1 in the developing endothelium is independent of TGF $\beta$ signaling and that TGF $\beta$ does not play a role in endothelial signaling functions related to the onset of HHT like phenotypes (Bailly, 2008).
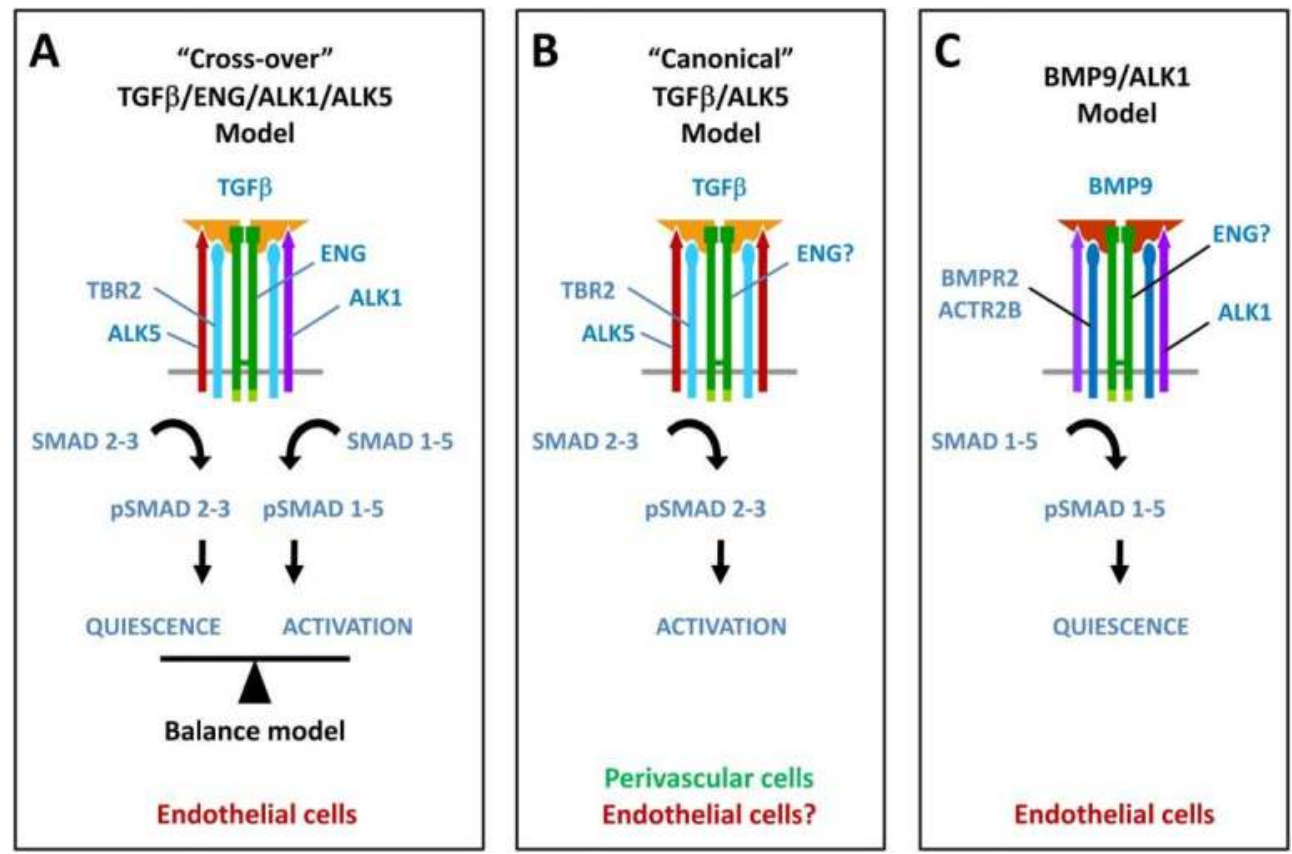

Fig. 6. Models of ALK1 / ENG mediated signaling in endothelial and perivascular cells. A. The "Cross-over" model proposes that TGF $\beta$ induces a dual ALK5/SMAD2-3 and ALK1/SMAD1-5 phosphorylation response in endothelial cells, whereby ALK1 signaling induces endothelial cell proliferation and migration, and antagonizes ALK5 signaling. B. The "canonical" TFG $\beta$ model proposes that TGF $\beta$-induced SMAD2-3 phosphorylation is central to perivascular cell biology. TGF $\beta$ may have endothelial functions unrelated to ALK1 signaling and HHT in vivo and ENG may play a role in transducing canonical TGF $\beta$ signaling. C. The BMP9 signaling model proposes that BMP9 is a circulating endothelial quiescence factor triggering SMAD1-5 signaling, resulting in endothelial quiescence.

\subsection{2 "Canonical" TGF $\beta$ / pSMAD2-3 signaling model}

In vivo studies have demonstrated a clear role for TGF $\beta / A L K 5$ signaling in vascular development (Pardali et al., 2010), but whether TGF $\beta$ signaling impacts endothelial cells in vivo remain a matter of controversy since endothelium-specific deletion of ALK5 and TBR2 do not disrupt the embryonic vasculature (Park et al., 2008). In vitro evidence suggests that the "canonical" TGF $\beta$ /SMAD2-3 signaling pathway is operative inside primary cultured endothelial cells (Fig. 6B). TGF $\beta$ induces SMAD2-3 phosphorylation in cultured endothelial cells (Bostrom et al., 2004; Goumans et al., 2002) and is reported to influence VEGF-A and PDGF-B transcript levels (Shao et al, 2009; Cunha et al., 2010). Moreover, ENG is detected in association with TBR2 and TGF $\beta$ in primary endothelial cells (Cheifetz et al., 1992; 
Yamashita et al., 1994); ENG can potentiate "canonical" TGF $/$ ALK5/SMAD2-3 signaling (Guerrero-Esteo et al., 2002); and the soluble extra-cellular domain of ENG can inhibit binding of TGF $\beta$ to endothelial cells and influence vascular tone (Venkatesha et al., 2006). Taken together, these results indicate that TGF $\beta$ may signal in endothelial cells, where it may have ALK1-independent, but ENG-dependent functions in the endothelium unrelated to the onset of HHT and vascular malformations, but related to the regulation of blood pressure (Venkatesha et al., 2006).

\subsubsection{BMP9 / SMAD1-5 signaling model}

An early study pointed to an unknown ligand present in human serum distinct from TGF $\beta$ that could activate ALK1 signaling (Lux et al., 1999). Following a report that BMP9 could be co-crystalized with ALK1 (Brown et al., 2005), other groups demonstrated that BMP9 and 10 were the only cognate ALK1 ligands within the TGF $\beta$ super-family (Mitchell et al., 2010) and that BMP9 and 10 triggered ALK1/SMAD1-5 signaling in primary endothelial cells (David et al., 2007; Scharpfenecker et al., 2007). BMP9 is produced by hepatic endothelial and stellate cells and was confirmed to be the ALK1 signaling trigger in human serum (David et al., 2008), while BMP10 is only detected during embryonic heart development (Neuhaus et al., 1999). BMP9 and 10 are the only TGF $\beta$ super-family ligands to bind ENG in the absence of other Type I or II receptors (Scharpfenecker et al., 2007), and ENG potentiates BMP9/ALK1/SMAD1-5 signaling in endothelial cells (David et al., 2007). Thus, a new model has emerged to explain the signaling pathway that is likely disrupted in the endothelium of HHT patients, whereby BMP9 triggers SMAD1-5 phosphorylation through a multimeric complex requiring ALK1, BMPR2 or ACTR2B and, possibly, ENG (Fig. 6C).

\subsection{Function of BMP9/ALK1/ENG signaling in endothelial cells in vitro and in vivo}

The response of endothelial cells to BMP9 appears to be context-dependent. In primary Human Dermal Microvascular Endothelial Cells (HMVEC-D), obtained from the skin, an organ whose vasculature is clearly affected in HHT patients, activation of ALK1 or stimulation with BMP9 inhibited cell proliferation and migration, while increasing SMAD15 target gene expression (David et al., 2007; Lamouille et al., 2002). Over-expression of ALK1 also decreased proliferation of primary HUVEC cells (Ota et al., 2002) and BMP9 blocked the proliferative effect of basic FGF (bFGF) on primary endothelial cells (Scharpfenecker et al., 2007). Based on these in vitro results, and on the fact that BMP9 inhibited vessel formation in a bFGF-driven in vivo angiogenesis assay (David et al., 2008), BMP9/ALK1 signaling was proposed to function in the resolution phase of angiogenesis, during which endothelial cell proliferation and migration shut down and vessel maturation and differentiation proceeds. According to this model, disruption of ALK1 signaling leads to endothelial cells that cannot stop proliferating and therefore cannot differentiate into mature functional vessels, leading to disruption of angiogenesis (David et al., 2009). Given that BMP9 and ALK1 repress the expression of pro-angiogenic factors in vitro (Shao et al., 2009) and in vivo (Oh et al., 2000), BMP9/ALK1 signaling may be key to the equilibrium between pro- and anti-angiogenic signals required for the completion of the activation and resolution phases of angiogenesis, which are both required for the formation of a functional vasculature.

Other studies reached opposite conclusions regarding the role of BMP9/ALK1 signaling in endothelial cells, supporting an alternative model in which BMP9 is proangiogenic. Suzuki and colleagues described that BMP9 stimulated the proliferation of MESEC cells (Suzuki et 
al., 2010), while other groups found that ALK1 and ENG stimulated MEEC proliferation (Goumans et al., 2002; Lebrin et al., 2004). As stated earlier, immortalized endothelial cells such as MESECs or MEECs are probably not the best models to define the physiological function of BMP9 and ALK1. However, the fact that BMP9 stimulated angiogenesis in a matrigel plug assay and a tumor model in vivo indicates that assay conditions, such as the concentration of proangiogenic factors, may influence the endothelium's response to BMP9/ ALK1 signaling (Suzuki et al., 2010).

\subsection{Development of therapeutics targeting ENG and ALK1}

Genetic evidence suggests that ENG and ALK1 functionally contribute to tumor angiogenesis. Cancer cells implanted in $\mathrm{ENG}^{+/-}$heterozygous mice produced tumors whose size and vascularization were reduced by $30 \%$ compared with tumors implanted in wildtype littermates (Duwel et al., 2007). The growth and vascularization of pancreatic neuroendocrine tumors were also reduced by $\sim 50 \%$ in $A L K 1^{+/-}$mice compared to $A L K 1^{+/+}$mice (Cunha et al., 2010). Together, these studies indicate that blocking ENG or ALK1 function could be an effective anti-tumor therapeutic strategy.

\subsubsection{Therapeutic agents targeting ALK1}

Agents targeting ALK1 have entered phase 1 clinical trials, including an ALK1-Fc peptibody from Acceleron (RAP-041) (Bendell et al., 2011) and an anti-ALK1 monoclonal antibody from Pfizer (Goff et al., 2010). ALK1-Fc sequesters ALK1 ligands such as BMP9 and BMP10 and inhibits their binding to endothelial ALK1 receptors (Cunha et al., 2010; David et al., 2007; Mitchell et al., 2010). ALK1-Fc prevented tumor growth in a neuro-endocrine pancreatic cancer model, accompanied by a significant decrease in tumor vascularization (Cunha and Pietras, 2011). ALK1-Fc also decreased the tumor burden of breast cancerimplanted mice by 75\% (Mitchell et al., 2010), suggesting that RAP-041 may induce an antiangiogenic response in cancer patients. Phase 1 results indicate preliminary signs of clinical activity but also a potential heart-related toxicity (Bendell et al., 2011).

The Pfizer antibody (PF-03446962) is a fully human monoclonal antibody that blocks seruminduced SMAD1-5 phosphorylation in endothelial cells (Hu-Lowe et al., 2011). A surrogate anti-mouse Alk1 antibody decreased tumor volume by $70 \%$ in a breast cancer model and decreased tumor microvascular density, indicating a potent anti-angiogenic effect $(\mathrm{Hu}-\mathrm{Lowe}$ et al., 2011). This antibody was not tested for its ability to inhibit BMP9 signaling specifically, but since serum-induced SMAD1 phosphorylation is largely due to the presence of circulating BMP9 (David et al., 2008), inhibition of BMP9 signaling is very likely a mechanism of action of this antibody. Importantly, the anti-mouse Alk1 antibody significantly improved the efficacy of VEGF/VEGFR pathway inhibition in a model of VEGF inhibitor-resistant melanoma, indicating the possibility that ALK1 inhibition may overcome mechanisms of resistance to VEGF inhibitors (Hu-Lowe et al., 2011). Preliminary evidence of clinical activity of PF03446962 has been reported without indications of adverse effects (Goff et al., 2010).

\subsubsection{Therapeutic anti-ENG monoclonal antibodies}

The clinical evaluation of TRC105, a chimeric human IgG1 anti-ENG antibody derived from the SN6j monoclonal mouse anti-human ENG antibody, has been initiated. SN6j has an antiproliferative effect on human endothelial cells in vitro (She et al., 2004) and decreased tumor growth in several mouse tumor models (Tsujie et al., 2006; Uneda et al., 2009). SN6j also 
inhibited lung and liver metastases in metastatic cancer models (Uneda et al., 2009). The anti-tumor mechanism of action of SN6j is thought to derive from its anti-angiogenic properties, as SN6j significantly decreased the vascularization of a matrigel plug assay (Tsujie et al., 2006). The SN6j antibody has not been tested for its ability to block BMP9 signaling in endothelial cells, but this possible mechanism of action should be explored. As an IgG1 chimeric antibody (Shiozaki et al., 2006), another possible mechanism of action of TRC105 could be the engagement of an antibody-dependent cell cytotoxic response (ADCC) targeted at the ENG-expressing cancer endothelium (Tsujie et al., 2008).

The results of a phase 1 trial indicate that TRC105 was well tolerated and there was preliminary evidence of clinical responses (Rosen et al., 2010). A phase 1-2 trial conducted in castrate-resistant prostate cancer patients confirmed the evidence of clinical responders, with patients who had progressed on anti-hormone therapies experiencing a significant decrease in PSA levels (Adelberg et al., 2011). Several phase 1 and 2 trials are now planned in Bladder, Breast, Renal and Liver cancer, including a combination trial with bevacizumab, an anti-VEGF-A antibody. This combination could prove efficacious since VEGF-A neutralization induces ENG expression in a pancreatic cancer model (Bockhorn et al., 2003), suggesting that ENG-dependent signaling may be engaged in response to VEGF-A inhibition as a possible adaptation mechanism.

\section{Conclusions}

In this chapter, we have reviewed signal transduction pathways (NOTCH and BMP9/ALK/ENG) whose key functions affect endothelial cell proliferation and vessel differentiation. As such, both pathways are critical for the resolution phase of angiogenesis, when endothelial cells complete their proliferation and migration in order to form a functional vasculature following recruitment of perivascular cells. NOTCH signaling determines the cell fate of stalk and tip cells, a step to limit vessel sprouting and allow organization into a functional vasculature. Endoglin and ALK1 define a receptor signaling complex which transduces BMP9 signaling in ECs. This signaling axis is critical for endothelial maturation and homeostasis, since even halving the expression or activity of these two proteins leads to hemorrhage and loss of perivascular cells. Both of these processes are distinct from the initiation phase of angiogenesis in which VEGF-A plays a central role. Therefore agents that interfere with NOTCH and ALK1/ENG signaling (1) are predicted to disrupt tumor angiogenesis as monotherapies as suggested by their preclinical activity, (2) may prove useful in combination with anti-VEGF inhibitors by targeting distinct phases of angiogenesis, provided there is no dose limiting toxicity due to the combination, and (3) may be able to overcome intrinsic and acquired resistance mechanisms to anti-VEGF therapeutics. With therapeutics to these pathways now progressing in clinical trials, the ability to target multiple phases of the angiogenic process to provide increased benefit to patients may be tested in the near future.

\section{Acknowledgements}

The authors thank Drs. Astrid Ruefli-Brasse, Terri Burgess, Dineli Wickramasinghe, Rick Kendall and Glenn Begley for their critical reading of the manuscript. Figures were adapted and reprinted under Creative Common license or with permission from Elsevier, the Massachusetts Medical Society and the American Association for Cancer Research. 


\section{References}

Acar, M., Jafar-Nejad, H., Takeuchi, H., Rajan, A., Ibrani, D., Rana, N.A., Pan, H., Haltiwanger, R.S., and Bellen, H.J. (2008). Rumi is a CAP10 domain glycosyltransferase that modifies Notch and is required for Notch signaling. Cell 132, 247-258.

Adelberg, D., Apolo, A.B., Madan, R.A., Gulley, J.L., Pierpoint, A., Kohler, D.R., Trepel, J.B., Steinberg, S.M., Figg, W.D., and Dahut, W.L. (2011). A phase I study of TRC105 (anti-CD105 monoclonal antibody) in metastatic castration-resistant prostate cancer (mCRPC). J Clin Oncol 29 s7, 171.

Altomonte, M., Montagner, R., Fonsatti, E., Colizzi, F., Cattarossi, I., Brasoveanu, L.I., Nicotra, M.R., Cattelan, A., Natali, P.G., and Maio, M. (1996). Expression and structural features of endoglin (CD105), a transforming growth factor beta1 and beta3 binding protein, in human melanoma. Br J Cancer 74, 1586-1591.

Arthur, H.M., Ure, J., Smith, A.J., Renforth, G., Wilson, D.I., Torsney, E., Charlton, R., Parums, D.V., Jowett, T., Marchuk, D.A., et al. (2000). Endoglin, an ancillary TGFbeta receptor, is required for extraembryonic angiogenesis and plays a key role in heart development. Dev Biol 217, 42-53.

Attisano, L., Carcamo, J., Ventura, F., Weis, F.M., Massague, J., and Wrana, J.L. (1993). Identification of human activin and TGF beta type I receptors that form heteromeric kinase complexes with type II receptors. Cell 75, 671-680.

Bailly, S. (2008). HHT is not a TGFb disease. Blood 111, 478.

Beckers, J., Clark, A., Wunsch, K., Hrabe De Angelis, M., and Gossler, A. (1999). Expression of the mouse Delta1 gene during organogenesis and fetal development. Mech Dev $84,165-168$.

Bendell, J.C., Gordon, M., Hurwitz, H., Yang, Y., Wilson, D.I., Haltom, E., Attie, K.M., Condon, C.H., Sherman, M.L., and Sharma, S. (2011). A Phase 1 dose escalating study with ACE-041, a novel inhibitor of ALK1 mediated angiogenesis, in patients with advanced solid tumors Paper presented at: AACR 102nd Annual Meeting (Orlando, FL, USA).

Benedito, R., Roca, C., Sorensen, I., Adams, S., Gossler, A., Fruttiger, M., and Adams, R.H. (2009). The notch ligands Dll4 and Jagged1 have opposing effects on angiogenesis. Cell 137, 1124-1135.

Bergers, G., and Hanahan, D. (2008). Modes of resistance to anti-angiogenic therapy. Nat Rev Cancer 8, 592-603.

Bergers, G., and Song, S. (2005). The role of pericytes in blood-vessel formation and maintenance. Neuro Oncol 7, 452-464.

Blaumueller, C.M., Qi, H., Zagouras, P., and Artavanis-Tsakonas, S. (1997). Intracellular cleavage of Notch leads to a heterodimeric receptor on the plasma membrane. Cell 90, 281-291.

Bockhorn, M., Tsuzuki, Y., Xu, L., Frilling, A., Broelsch, C.E., and Fukumura, D. (2003). Differential vascular and transcriptional responses to anti-vascular endothelial growth factor antibody in orthotopic human pancreatic cancer xenografts. Clin Cancer Res 9, 4221-4226.

Bostrom, K., Zebboudj, A.F., Yao, Y., Lin, T.S., and Torres, A. (2004). Matrix GLA protein stimulates VEGF expression through increased transforming growth factor-beta1 activity in endothelial cells. J Biol Chem 279, 52904-52913. 
Bourdeau, A., Dumont, D.J., and Letarte, M. (1999). A murine model of hereditary hemorrhagic telangiectasia. J Clin Invest 104, 1343-1351.

Brown, M.A., Zhao, Q., Baker, K.A., Naik, C., Chen, C., Pukac, L., Singh, M., Tsareva, T., Parice, Y., Mahoney, A., et al. (2005). Crystal structure of BMP-9 and functional interactions with pro-region and receptors. J Biol Chem 280, 25111-25118.

Burrows, F.J., Derbyshire, E.J., Tazzari, P.L., Amlot, P., Gazdar, A.F., King, S.W., Letarte, M., Vitetta, E.S., and Thorpe, P.E. (1995). Up-regulation of endoglin on vascular endothelial cells in human solid tumors: implications for diagnosis and therapy. Clin Cancer Res 1, 1623-1634.

Casanovas, O. (2011). The adaptive stroma joining the antiangiogenic resistance front. J Clin Invest.

Cheifetz, S., Bellon, T., Cales, C., Vera, S., Bernabeu, C., Massague, J., and Letarte, M. (1992). Endoglin is a component of the transforming growth factor-beta receptor system in human endothelial cells. J Biol Chem 267, 19027-19030.

Chen, F., Yu, G., Arawaka, S., Nishimura, M., Kawarai, T., Yu, H., Tandon, A., Supala, A., Song, Y.Q., Rogaeva, E., et al. (2001). Nicastrin binds to membrane-tethered Notch. Nat Cell Biol 3, 751-754.

Conlon, R.A., Reaume, A.G., and Rossant, J. (1995). Notch1 is required for the coordinate segmentation of somites. Development 121, 1533-1545.

Crawford, Y., and Ferrara, N. (2009). Tumor and stromal pathways mediating refractoriness/resistance to anti-angiogenic therapies. Trends Pharmacol Sci 30, 624-630.

Cunha, S.I., Pardali, E., Thorikay, M., Anderberg, C., Hawinkels, L., Goumans, M.J., Seehra, J., Heldin, C.H., ten Dijke, P., and Pietras, K. (2010). Genetic and pharmacological targeting of activin receptor-like kinase 1 impairs tumor growth and angiogenesis. J Exp Med 207, 85-100.

Cunha, S.I., and Pietras, K. (2011). ALK1 as an emerging target for anti-angiogenic therapy for cancer. Blood 117 (15).

Dallas, N.A., Samuel, S., Xia, L., Fan, F., Gray, M.J., Lim, S.J., and Ellis, L.M. (2008). Endoglin (CD105): a marker of tumor vasculature and potential target for therapy. Clin Cancer Res 14, 1931-1937.

Daly, A.C., Randall, R.A., and Hill, C.S. (2008). Transforming growth factor beta-induced Smad1/5 phosphorylation in epithelial cells is mediated by novel receptor complexes and is essential for anchorage-independent growth. Mol Cell Biol 28, 6889-6902.

David, L., Feige, J.J., and Bailly, S. (2009). Emerging role of bone morphogenetic proteins in angiogenesis. Cytokine Growth Factor Rev 20, 203-212.

David, L., Mallet, C., Keramidas, M., Lamande, N., Gasc, J.M., Dupuis-Girod, S., Plauchu, H., Feige, J.J., and Bailly, S. (2008). Bone morphogenetic protein-9 is a circulating vascular quiescence factor. Circulation Research 102, 914-922.

David, L., Mallet, C., Mazerbourg, S., Feige, J.J., and Bailly, S. (2007). Identification of BMP9 and BMP10 as functional activators of the orphan activin receptor-like kinase 1 (ALK1) in endothelial cells. Blood 109, 1953-1961.

Djokovic, D., Trindade, A., Gigante, J., Badenes, M., Silva, L., Liu, R., Li, X., Gong, M., Krasnoperov, V., Gill, P.S., et al. (2010). Combination of Dll4/Notch and Ephrin- 
B2/EphB4 targeted therapy is highly effective in disrupting tumor angiogenesis. BMC Cancer 10, 641.

Domenga, V., Fardoux, P., Lacombe, P., Monet, M., Maciazek, J., Krebs, L.T., Klonjkowski, B., Berrou, E., Mericskay, M., Li, Z., et al. (2004). Notch3 is required for arterial identity and maturation of vascular smooth muscle cells. Genes \& Development 18, 2730-2735.

Duwel, A., Eleno, N., Jerkic, M., Arevalo, M., Bolanos, J.P., Bernabeu, C., and Lopez-Novoa, J.M. (2007). Reduced tumor growth and angiogenesis in endoglin-haploinsufficient mice. Tumour Biol 28, 1-8.

Eiraku, M., Tohgo, A., Ono, K., Kaneko, M., Fujishima, K., Hirano, T., and Kengaku, M. (2005). DNER acts as a neuron-specific Notch ligand during Bergmann glial development. Nature Neuroscience 8, 873-880.

Ellis, L.M., and Hicklin, D.J. (2008). VEGF-targeted therapy: mechanisms of anti-tumour activity. Nat Rev Cancer 8, 579-591.

Fernandez, L.A., Sanz-Rodriguez, F., Zarrabeitia, R., Perez-Molino, A., Hebbel, R.P., Nguyen, J., Bernabeu, C., and Botella, L.M. (2005). Blood outgrowth endothelial cells from Hereditary Haemorrhagic Telangiectasia patients reveal abnormalities compatible with vascular lesions. Cardiovasc Res 68, 235-248.

Finnson, K.W., Parker, W.L., ten Dijke, P., Thorikay, M., and Philip, A. (2008). ALK1 opposes ALK5/Smad3 signaling and expression of extracellular matrix components in human chondrocytes. J Bone Miner Res 23, 896-906.

Fonsatti, E., Del Vecchio, L., Altomonte, M., Sigalotti, L., Nicotra, M.R., Coral, S., Natali, P.G., and Maio, M. (2001). Endoglin: An accessory component of the TGF-betabinding receptor-complex with diagnostic, prognostic, and bioimmunotherapeutic potential in human malignancies. J Cell Physiol 188, 1-7.

Fryer, C.J., Lamar, E., Turbachova, I., Kintner, C., and Jones, K.A. (2002). Mastermind mediates chromatin-specific transcription and turnover of the Notch enhancer complex. Genes \& Development 16, 1397-1411.

Fryer, C.J., White, J.B., and Jones, K.A. (2004). Mastermind recruits CycC:CDK8 to phosphorylate the Notch ICD and coordinate activation with turnover. Molecular Cell 16, 509-520.

Funahashi, Y., Hernandez, S.L., Das, I., Ahn, A., Huang, J., Vorontchikhina, M., Sharma, A., Kanamaru, E., Borisenko, V., Desilva, D.M., et al. (2008). A notch1 ectodomain construct inhibits endothelial notch signaling, tumor growth, and angiogenesis. Cancer Research 68, 4727-4735.

Gale, N.W., Dominguez, M.G., Noguera, I., Pan, L., Hughes, V., Valenzuela, D.M., Murphy, A.J., Adams, N.C., Lin, H.C., Holash, J., et al. (2004). Haploinsufficiency of delta-like 4 ligand results in embryonic lethality due to major defects in arterial and vascular development. Proceedings of the National Academy of Sciences of the United States of America 101, 15949-15954.

Garrido-Martin, E.M., Blanco, F.J., Fernandez, L.A., Langa, C., Vary, C.P., Lee, U.E., Friedman, S.L., Botella, L.M., and Bernabeu, C. (2010). Characterization of the human Activin-A receptor type II-like kinase 1 (ACVRL1) promoter and its regulation by Sp1. BMC Mol Biol 11, 51 .

Goff, L.W., De Braud, F.G., Cohen, R.B., Berlin, J., Noberasco, C., Borghaei, H., Wang, E., Hu-Lowe, D., Levin, W.J., and Gallo-Stampino, C. (2010). Phase I study of PF- 
03446962, a fully human mab against ALK 1, a TGFß receptor involved in tumor angiogenesis. J Clin Oncol 28.

Gordon, W.R., Arnett, K.L., and Blacklow, S.C. (2008). The molecular logic of Notch signaling--a structural and biochemical perspective. J Cell Sci 121, 3109-3119.

Gordon, W.R., Vardar-Ulu, D., Histen, G., Sanchez-Irizarry, C., Aster, J.C., and Blacklow, S.C. (2007). Structural basis for autoinhibition of Notch.[erratum appears in Nat Struct Mol Biol. 2007 May;14(5):455]. Nature Structural \& Molecular Biology 14, 295-300.

Gougos, A., and Letarte, M. (1988). Identification of a human endothelial cell antigen with monoclonal antibody 44G4 produced against a pre-B leukemic cell line. J Immunol 141, 1925-1933.

Gougos, A., and Letarte, M. (1990). Primary structure of endoglin, an RGD-containing glycoprotein of human endothelial cells. J Biol Chem 265, 8361-8364.

Goumans, M.J., Valdimarsdottir, G., Itoh, S., Lebrin, F., Larsson, J., Mummery, C., Karlsson, S., and ten Dijke, P. (2003). Activin receptor-like kinase (ALK)1 is an antagonistic mediator of lateral TGFbeta/ ALK5 signaling. Mol Cell 12, 817-828.

Goumans, M.J., Valdimarsdottir, G., Itoh, S., Rosendahl, A., Sideras, P., and ten Dijke, P. (2002). Balancing the activation state of the endothelium via two distinct TGF-beta type I receptors. EMBO J 21, 1743-1753.

Guerrero-Esteo, M., Sanchez-Elsner, T., Letamendia, A., and Bernabeu, C. (2002). Extracellular and cytoplasmic domains of endoglin interact with the transforming growth factor-beta receptors I and II. J Biol Chem 277, 29197-29209.

Guttmacher, A.E., Marchuk, D.A., and White, R.I., Jr. (1995). Hereditary hemorrhagic telangiectasia. N Engl J Med 333, 918-924.

Haines, N., and Irvine, K.D. (2003). Glycosylation regulates Notch signalling. Nat Rev Mol Cell Biol 4, 786-797.

Hamada, Y., Kadokawa, Y., Okabe, M., Ikawa, M., Coleman, J.R., and Tsujimoto, Y. (1999). Mutation in ankyrin repeats of the mouse Notch2 gene induces early embryonic lethality. Development 126, 3415-3424.

Hanahan, D., and Weinberg, R.A. (2011). Hallmarks of cancer: the next generation. Cell 144, 646-674.

Hanlon, L., Avila, J.L., Demarest, R.M., Troutman, S., Allen, M., Ratti, F., Rustgi, A.K., Stanger, B.Z., Radtke, F., Adsay, V., et al. (2010). Notch1 functions as a tumor suppressor in a model of K-ras-induced pancreatic ductal adenocarcinoma. Cancer Research 70, 4280-4286.

Haritunians, T., Boulter, J., Hicks, C., Buhrman, J., DiSibio, G., Shawber, C., Weinmaster, G., Nofziger, D., and Schanen, C. (2002). CADASIL Notch3 mutant proteins localize to the cell surface and bind ligand. Circ Res 90, 506-508.

Hauschild, A., Agarwala, S.S., Trefzer, U., Hogg, D., Robert, C., Hersey, P., Eggermont, A., Grabbe, S., Gonzalez, R., Gille, J., et al. (2009). Results of a phase III, randomized, placebo-controlled study of sorafenib in combination with carboplatin and paclitaxel as second-line treatment in patients with unresectable stage III or stage IV melanoma. J Clin Oncol 27, 2823-2830.

High, F.A., Lu, M.M., Pear, W.S., Loomes, K.M., Kaestner, K.H., and Epstein, J.A. (2008). Endothelial expression of the Notch ligand Jagged1 is required for vascular smooth 
muscle development. Proceedings of the National Academy of Sciences of the United States of America 105, 1955-1959.

Hingorani, S.R., Petricoin, E.F., Maitra, A., Rajapakse, V., King, C., Jacobetz, M.A., Ross, S., Conrads, T.P., Veenstra, T.D., Hitt, B.A., et al. (2003). Preinvasive and invasive ductal pancreatic cancer and its early detection in the mouse. Cancer Cell 4, 437450.

Hoey, T., Yen, W.C., Axelrod, F., Basi, J., Donigian, L., Dylla, S., Fitch-Bruhns, M., Lazetic, S., Park, I.K., Sato, A., et al. (2009). DLL4 blockade inhibits tumor growth and reduces tumor-initiating cell frequency. Cell Stem Cell 5, 168-177.

Hrabe de Angelis, M., McIntyre, J., 2nd, and Gossler, A. (1997). Maintenance of somite borders in mice requires the Delta homologue DII1. Nature 386, 717-721.

Hu-Lowe, D.D., Chen, E., Zhang, L., Watson, K.D., Mancuso, P., Lappin, P., Wickman, G., Chen, J.H., Wang, J., Jiang, X., et al. (2011). Targeting Activin Receptor-Like Kinase 1 Inhibits Angiogenesis and Tumorigenesis through a Mechanism of Action Complementary to Anti-VEGF Therapies. Cancer Res 71, 1362-1373.

Hu, Q.D., Ang, B.T., Karsak, M., Hu, W.P., Cui, X.Y., Duka, T., Takeda, Y., Chia, W., Sankar, N., Ng, Y.K., et al. (2003). F3/contactin acts as a functional ligand for Notch during oligodendrocyte maturation. Cell 115, 163-175.

Hurwitz, H., Fehrenbacher, L., Novotny, W., Cartwright, T., Hainsworth, J., Heim, W., Berlin, J., Baron, A., Griffing, S., Holmgren, E., et al. (2004). Bevacizumab plus irinotecan, fluorouracil, and leucovorin for metastatic colorectal cancer. N Engl J Med 350, 2335-2342.

Iso, T., Kedes, L., and Hamamori, Y. (2003). HES and HERP families: multiple effectors of the Notch signaling pathway. J Cell Physiol 194, 237-255.

Jakobsson, L., Franco, C.A., Bentley, K., Collins, R.T., Ponsioen, B., Aspalter, I.M., Rosewell, I., Busse, M., Thurston, G., Medvinsky, A., et al. (2010). Endothelial cells dynamically compete for the tip cell position during angiogenic sprouting. Nat Cell Biol 12, 943-953.

Jarriault, S., Brou, C., Logeat, F., Schroeter, E.H., Kopan, R., and Israel, A. (1995). Signalling downstream of activated mammalian Notch.[see comment]. Nature 377, 355-358.

Johnson, D.W., Berg, J.N., Baldwin, M.A., Gallione, C.J., Marondel, I., Yoon, S.J., Stenzel, T.T., Speer, M., Pericak-Vance, M.A., Diamond, A., et al. (1996). Mutations in the activin receptor-like kinase 1 gene in hereditary haemorrhagic telangiectasia type 2 . Nat Genet 13, 189-195.

Jonker, L., and Arthur, H.M. (2002). Endoglin expression in early development is associated with vasculogenesis and angiogenesis. Mech Dev 110, 193-196.

Joutel, A., Andreux, F., Gaulis, S., Domenga, V., Cecillon, M., Battail, N., Piga, N., Chapon, F., Godfrain, C., and Tournier-Lasserve, E. (2000). The ectodomain of the Notch3 receptor accumulates within the cerebrovasculature of CADASIL patients. J Clin Invest 105, 597-605.

Joutel, A., Corpechot, C., Ducros, A., Vahedi, K., Chabriat, H., Mouton, P., Alamowitch, S., Domenga, V., Cecillion, M., Marechal, E., et al. (1996). Notch3 mutations in CADASIL, a hereditary adult-onset condition causing stroke and dementia. Nature 383, 707-710.

Jubb, A.M., Miller, K.D., Rugo, H.S., Harris, A.L., Chen, D., Reimann, J.D., Cobleigh, M.A., Schmidt, M., Langmuir, V.K., Hillan, K.J., et al. (2011). Impact of exploratory 
biomarkers on the treatment effect of bevacizumab in metastatic breast cancer. Clin Cancer Res 17, 372-381.

Jubb, A.M., Turley, H., Moeller, H.C., Steers, G., Han, C., Li, J.L., Leek, R., Tan, E.Y., Singh, B., Mortensen, N.J., et al. (2009). Expression of delta-like ligand 4 (Dll4) and markers of hypoxia in colon cancer. Br J Cancer 101, 1749-1757.

Kerbel, R.S. (2008). Tumor angiogenesis. N Engl J Med 358, 2039-2049.

Kindler, H.L., Niedzwiecki, D., Hollis, D., Oraefo, E., Schrag, D., and Hurwitz, H. (2007). A double-blind, placebo-controlled, randomized phase III trial of gemcitabine plus bevacizumab versus gemcitabine plus placebo in patients with advanced pancreatic cancer. J Clin Oncol 25, 4508.

Klinakis, A., Lobry, C., Abdel-Wahab, O., Oh, P., Haeno, H., Buonamici, S., van De Walle, I., Cathelin, S., Trimarchi, T., Araldi, E., et al. (2011). A novel tumour-suppressor function for the Notch pathway in myeloid leukaemia. Nature 473, 230-233.

Kopan, R., and Ilagan, M.X. (2009). The canonical Notch signaling pathway: unfolding the activation mechanism. Cell 137, 216-233.

Kopetz, S., Hoff, P.M., Morris, J.S., Wolff, R.A., Eng, C., Glover, K.Y., Adinin, R., Overman, M.J., Valero, V., Wen, S., et al. (2010). Phase II trial of infusional fluorouracil, irinotecan, and bevacizumab for metastatic colorectal cancer: efficacy and circulating angiogenic biomarkers associated with therapeutic resistance. J Clin Oncol 28, 453-459.

Krebs, L.T., Shutter, J.R., Tanigaki, K., Honjo, T., Stark, K.L., and Gridley, T. (2004). Haploinsufficient lethality and formation of arteriovenous malformations in Notch pathway mutants. Genes \& Development 18, 2469-2473.

Krebs, L.T., Xue, Y., Norton, C.R., Shutter, J.R., Maguire, M., Sundberg, J.P., Gallahan, D., Closson, V., Kitajewski, J., Callahan, R., et al. (2000). Notch signaling is essential for vascular morphogenesis in mice. Genes \& Development 14, 1343-1352.

Krebs, L.T., Xue, Y., Norton, C.R., Sundberg, J.P., Beatus, P., Lendahl, U., Joutel, A., and Gridley, T. (2003). Characterization of Notch3-deficient mice: normal embryonic development and absence of genetic interactions with a Notch1 mutation. Genesis 37, 139-143.

Lamouille, S., Mallet, C., Feige, J.J., and Bailly, S. (2002). Activin receptor-like kinase 1 is implicated in the maturation phase of angiogenesis. Blood 100, 4495-4501.

Larsson, J., Goumans, M.J., Sjostrand, L.J., van Rooijen, M.A., Ward, D., Leveen, P., Xu, X., ten Dijke, P., Mummery, C.L., and Karlsson, S. (2001). Abnormal angiogenesis but intact hematopoietic potential in TGF-beta type I receptor-deficient mice. EMBO J 20, 1663-1673.

Lebrin, F., Goumans, M.J., Jonker, L., Carvalho, R.L., Valdimarsdottir, G., Thorikay, M., Mummery, C., Arthur, H.M., and ten Dijke, P. (2004). Endoglin promotes endothelial cell proliferation and TGF-beta/ALK1 signal transduction. EMBO J 23, 4018-4028.

Lebrin, F., and Mummery, C.L. (2008). Endoglin-mediated vascular remodeling: mechanisms underlying hereditary hemorrhagic telangiectasia. Trends Cardiovasc Med 18, 25-32.

Li, C., Issa, R., Kumar, P., Hampson, I.N., Lopez-Novoa, J.M., Bernabeu, C., and Kumar, S. (2003). CD105 prevents apoptosis in hypoxic endothelial cells. J Cell Sci 116, 26772685. 
Li, D.Y., Sorensen, L.K., Brooke, B.S., Urness, L.D., Davis, E.C., Taylor, D.G., Boak, B.B., and Wendel, D.P. (1999). Defective angiogenesis in mice lacking endoglin. Science 284, 1534-1537.

Lieber, T., Kidd, S., Alcamo, E., Corbin, V., and Young, M.W. (1993). Antineurogenic phenotypes induced by truncated Notch proteins indicate a role in signal transduction and may point to a novel function for Notch in nuclei. Genes \& Development 7, 1949-1965.

Limbourg, A., Ploom, M., Elligsen, D., Sorensen, I., Ziegelhoeffer, T., Gossler, A., Drexler, H., and Limbourg, F.P. (2007). Notch ligand Delta-like 1 is essential for postnatal arteriogenesis. Circ Res 100, 363-371.

Limbourg, F.P., Takeshita, K., Radtke, F., Bronson, R.T., Chin, M.T., and Liao, J.K. (2005). Essential role of endothelial Notch1 in angiogenesis. Circulation 111, 1826-1832.

Liu, I.M., Schilling, S.H., Knouse, K.A., Choy, L., Derynck, R., and Wang, X.F. (2009). TGFbeta-stimulated Smad1/5 phosphorylation requires the ALK5 L45 loop and mediates the pro-migratory TGFbeta switch. EMBO J 28, 88-98.

Liu, Z., Turkoz, A., Jackson, E.N., Corbo, J.C., Engelbach, J.A., Garbow, J.R., PiwnicaWorms, D.R., and Kopan, R. (2011). Notch1 loss of heterozygosity causes vascular tumors and lethal hemorrhage in mice. J Clin Invest 121, 800-808.

Llovet, J.M., Ricci, S., Mazzaferro, V., Hilgard, P., Gane, E., Blanc, J.F., de Oliveira, A.C., Santoro, A., Raoul, J.L., Forner, A., et al. (2008). Sorafenib in advanced hepatocellular carcinoma. N Engl J Med 359, 378-390.

Lobov, I.B., Renard, R.A., Papadopoulos, N., Gale, N.W., Thurston, G., Yancopoulos, G.D., and Wiegand, S.J. (2007). Delta-like ligand 4 (Dll4) is induced by VEGF as a negative regulator of angiogenic sprouting. Proceedings of the National Academy of Sciences of the United States of America 104, 3219-3224.

Logeat, F., Bessia, C., Brou, C., LeBail, O., Jarriault, S., Seidah, N.G., and Israel, A. (1998). The Notch1 receptor is cleaved constitutively by a furin-like convertase. Proceedings of the National Academy of Sciences of the United States of America 95, 8108-8112.

Loges, S., Schmidt, T., and Carmeliet, P. (2010). Mechanisms of resistance to anti-angiogenic therapy and development of third generation anti-angiogenic drug candidates. Genes Cancer 1, 12-25.

Loomes, K.M., Taichman, D.B., Glover, C.L., Williams, P.T., Markowitz, J.E., Piccoli, D.A., Baldwin, H.S., and Oakey, R.J. (2002). Characterization of Notch receptor expression in the developing mammalian heart and liver. Am J Med Genet 112, 181-189.

Lux, A., Attisano, L., and Marchuk, D.A. (1999). Assignment of transforming growth factor beta 1 and beta3 and a third new ligand to the type I receptor ALK-1. J Biol Chem 274, 9984-9992.

Massague, J. (2000). How cells read TGF-beta signals. Nat Rev Mol Cell Biol 1, 169-178.

McAllister, K.A., Grogg, K.M., Johnson, D.W., Gallione, C.J., Baldwin, M.A., Jackson, C.E., Helmbold, E.A., Markel, D.S., McKinnon, W.C., Murrell, J., et al. (1994). Endoglin, a TGF-beta binding protein of endothelial cells, is the gene for hereditary haemorrhagic telangiectasia type 1 . Nat Genet 8, 345-351.

McCright, B., Gao, X., Shen, L., Lozier, J., Lan, Y., Maguire, M., Herzlinger, D., Weinmaster, G., Jiang, R., and Gridley, T. (2001). Defects in development of the kidney, heart 
and eye vasculature in mice homozygous for a hypomorphic Notch2 mutation. Development 128, 491-502.

McCright, B., Lozier, J., and Gridley, T. (2002). A mouse model of Alagille syndrome: Notch2 as a genetic modifier of Jag1 haploinsufficiency. Development 129, 10751082.

Miller, D.W., Graulich, W., Karges, B., Stahl, S., Ernst, M., Ramaswamy, A., Sedlacek, H.H., Muller, R., and Adamkiewicz, J. (1999). Elevated expression of endoglin, a component of the TGF-beta-receptor complex, correlates with proliferation of tumor endothelial cells. Int J Cancer 81, 568-572.

Miller, K., Wang, M., Gralow, J., Dickler, M., Cobleigh, M., Perez, E.A., Shenkier, T., Cella, D., and Davidson, N.E. (2007). Paclitaxel plus bevacizumab versus paclitaxel alone for metastatic breast cancer. N Engl J Med 357, 2666-2676.

Minhajat, R., Mori, D., Yamasaki, F., Sugita, Y., Satoh, T., and Tokunaga, O. (2006). Organspecific endoglin (CD105) expression in the angiogenesis of human cancers. Pathol Int $56,717-723$.

Mitchell, D., Pobre, E.G., Mulivor, A.W., Grinberg, A.V., Castonguay, R., Monnell, T.E., Solban, N., Ucran, J.A., Pearsall, R.S., Underwood, K.W., et al. (2010). ALK1-Fc inhibits multiple mediators of angiogenesis and suppresses tumor growth. Mol Cancer Ther 9, 379-388.

Mohr, O.L. (1919). Character Changes Caused by Mutation of an Entire Region of a Chromosome in Drosophila. Genetics 4, 275-282.

Moloney, D.J., Panin, V.M., Johnston, S.H., Chen, J., Shao, L., Wilson, R., Wang, Y., Stanley, P., Irvine, K.D., Haltiwanger, R.S., et al. (2000). Fringe is a glycosyltransferase that modifies Notch.[see comment]. Nature 406, 369-375.

Morgan, T.H., and Bridges, C.B. (1916). Sex-linked inheritance in Drosophila (Carnegie Institution of Washington).

Motzer, R.J., Hutson, T.E., Tomczak, P., Michaelson, M.D., Bukowski, R.M., Oudard, S., Negrier, S., Szczylik, C., Pili, R., Bjarnason, G.A., et al. (2009). Overall survival and updated results for sunitinib compared with interferon alfa in patients with metastatic renal cell carcinoma. J Clin Oncol 27, 3584-3590.

Neuhaus, H., Rosen, V., and Thies, R.S. (1999). Heart specific expression of mouse BMP-10 a novel member of the TGF-beta superfamily. Mech Dev 80, 181-184.

Nicolas, M., Wolfer, A., Raj, K., Kummer, J.A., Mill, P., van Noort, M., Hui, C.C., Clevers, H., Dotto, G.P., and Radtke, F. (2003). Notch1 functions as a tumor suppressor in mouse skin. Nat Genet 33, 416-421.

Noguera-Troise, I., Daly, C., Papadopoulos, N.J., Coetzee, S., Boland, P., Gale, N.W., Lin, H.C., Yancopoulos, G.D., and Thurston, G. (2006). Blockade of Dll4 inhibits tumour growth by promoting non-productive angiogenesis.[see comment]. Nature 444, 1032-1037.

Oberg, C., Li, J., Pauley, A., Wolf, E., Gurney, M., and Lendahl, U. (2001). The Notch intracellular domain is ubiquitinated and negatively regulated by the mammalian Sel-10 homolog. J Biol Chem 276, 35847-35853.

Oh, S.P., Seki, T., Goss, K.A., Imamura, T., Yi, Y., Donahoe, P.K., Li, L., Miyazono, K., ten Dijke, P., Kim, S., et al. (2000). Activin receptor-like kinase 1 modulates transforming growth factor-beta 1 signaling in the regulation of angiogenesis. Proc Natl Acad Sci U S A 97, 2626-2631. 
Ohtsuka, T., Ishibashi, M., Gradwohl, G., Nakanishi, S., Guillemot, F., and Kageyama, R. (1999). Hes1 and Hes5 as notch effectors in mammalian neuronal differentiation. EMBO Journal 18, 2196-2207.

Ong, C.-T., Cheng, H.-T., Chang, L.-W., Ohtsuka, T., Kageyama, R., Stormo, G.D., and Kopan, R. (2006). Target selectivity of vertebrate notch proteins. Collaboration between discrete domains and CSL-binding site architecture determines activation probability. J Biol Chem 281, 5106-5119.

Ota, T., Fujii, M., Sugizaki, T., Ishii, M., Miyazawa, K., Aburatani, H., and Miyazono, K. (2002). Targets of transcriptional regulation by two distinct type I receptors for transforming growth factor-beta in human umbilical vein endothelial cells. J Cell Physiol 193, 299-318.

Panchenko, M.P., Williams, M.C., Brody, J.S., and Yu, Q. (1996). Type I receptor serinethreonine kinase preferentially expressed in pulmonary blood vessels. Am J Physiol 270, L547-558.

Pardali, E., Goumans, M.J., and ten Dijke, P. (2010). Signaling by members of the TGF-beta family in vascular morphogenesis and disease. Trends Cell Biol 20, 556-567.

Park, S.O., Lee, Y.J., Seki, T., Hong, K.H., Fliess, N., Jiang, Z., Park, A., Wu, X., Kaartinen, V., Roman, B.L., et al. (2008). ALK5- and TGFBR2-independent role of ALK1 in the pathogenesis of hereditary hemorrhagic telangiectasia type 2. Blood 111, 633-642.

Patel, N.S., Dobbie, M.S., Rochester, M., Steers, G., Poulsom, R., Le Monnier, K., Cranston, D.W., Li, J.L., and Harris, A.L. (2006). Up-regulation of endothelial delta-like 4 expression correlates with vessel maturation in bladder cancer. Clinical Cancer Research 12, 4836-4844.

Patel, N.S., Li, J.L., Generali, D., Poulsom, R., Cranston, D.W., and Harris, A.L. (2005). Upregulation of delta-like 4 ligand in human tumor vasculature and the role of basal expression in endothelial cell function. Cancer Research 65, 8690-8697.

Pece-Barbara, N., Cymerman, U., Vera, S., Marchuk, D.A., and Letarte, M. (1999). Expression analysis of four endoglin missense mutations suggests that haploinsufficiency is the predominant mechanism for hereditary hemorrhagic telangiectasia type 1 . Hum Mol Genet 8, 2171-2181.

Ricard, N., Bidart, M., Mallet, C., Lesca, G., Giraud, S., Prudent, R., Feige, J.J., and Bailly, S. (2010). Functional analysis of the BMP9 response of ALK1 mutants from HHT2 patients: a diagnostic tool for novel ACVRL1 mutations. Blood 116, 1604-1612.

Ridgway, J., Zhang, G., Wu, Y., Stawicki, S., Liang, W.C., Chanthery, Y., Kowalski, J., Watts, R.J., Callahan, C., Kasman, I., et al. (2006). Inhibition of Dll4 signalling inhibits tumour growth by deregulating angiogenesis.[see comment]. Nature 444, 10831087.

Rini, B.I., and Atkins, M.B. (2009). Resistance to targeted therapy in renal-cell carcinoma. Lancet Oncol 10, 992-1000.

Risau, W. (1997). Mechanisms of angiogenesis. Nature 386, 671-674.

Roelen, B.A., van Rooijen, M.A., and Mummery, C.L. (1997). Expression of ALK-1, a type 1 serine/threonine kinase receptor, coincides with sites of vasculogenesis and angiogenesis in early mouse development. Dev Dyn 209, 418-430.

Rosen, L.S., Gordon, M.S., Hurwitz, H.I., Wong, M., Adams, B.J., Alvarez, D., Seon, B.K., Leigh, B.R., and Theuer, C.P. (2010). A first in human phase 1 study of Anti-CD105 (Anti-endoglin) antibody therapy with TRC105 in patients with advanced solid 
tumors. Paper presented at: 22nd EORTC-NCI-AACR Symposium on Molecular Targets and Cancer Therapeutics (Berlin, Germany).

Sanchez-Elsner, T., Botella, L.M., Velasco, B., Langa, C., and Bernabeu, C. (2002). Endoglin expression is regulated by transcriptional cooperation between the hypoxia and transforming growth factor-beta pathways. J Biol Chem 277, 43799-43808.

Sanchez-Irizarry, C., Carpenter, A.C., Weng, A.P., Pear, W.S., Aster, J.C., and Blacklow, S.C. (2004). Notch subunit heterodimerization and prevention of ligand-independent proteolytic activation depend, respectively, on a novel domain and the LNR repeats. Molecular \& Cellular Biology 24, 9265-9273.

Sandler, A., Gray, R., Perry, M.C., Brahmer, J., Schiller, J.H., Dowlati, A., Lilenbaum, R., and Johnson, D.H. (2006). Paclitaxel-carboplatin alone or with bevacizumab for nonsmall-cell lung cancer. N Engl J Med 355, 2542-2550.

Scharpfenecker, M., van Dinther, M., Liu, Z., van Bezooijen, R.L., Zhao, Q., Pukac, L., Lowik, C.W., and ten Dijke, P. (2007). BMP-9 signals via ALK1 and inhibits bFGF-induced endothelial cell proliferation and VEGF-stimulated angiogenesis. J Cell Sci 120, 964972.

Schroeter, E.H., Kisslinger, J.A., and Kopan, R. (1998). Notch-1 signalling requires ligandinduced proteolytic release of intracellular domain.[see comment]. Nature 393, 382386.

Seki, T., Hong, K.H., and Oh, S.P. (2006). Nonoverlapping expression patterns of ALK1 and ALK5 reveal distinct roles of each receptor in vascular development. Lab Invest 86, 116-129.

Seki, T., Yun, J., and Oh, S.P. (2003). Arterial endothelium-specific activin receptor-like kinase 1 expression suggests its role in arterialization and vascular remodeling. Circ Res 93, 682-689.

Shao, E.S., Lin, L., Yao, Y., and Bostrom, K.I. (2009). Expression of vascular endothelial growth factor is coordinately regulated by the activin-like kinase receptors 1 and 5 in endothelial cells. Blood 114, 2197-2206.

She, X., Matsuno, F., Harada, N., Tsai, H., and Seon, B.K. (2004). Synergy between antiendoglin (CD105) monoclonal antibodies and TGF-beta in suppression of growth of human endothelial cells. Int J Cancer 108, 251-257.

Shiozaki, K., Harada, N., Greco, W.R., Haba, A., Uneda, S., Tsai, H., and Seon, B.K. (2006). Antiangiogenic chimeric anti-endoglin (CD105) antibody: pharmacokinetics and immunogenicity in nonhuman primates and effects of doxorubicin. Cancer Immunol Immunother 55, 140-150.

Shutter, J.R., Scully, S., Fan, W., Richards, W.G., Kitajewski, J., Deblandre, G.A., Kintner, C.R., and Stark, K.L. (2000). Dll4, a novel Notch ligand expressed in arterial endothelium. Genes \& Development 14, 1313-1318.

Sorensen, I., Adams, R.H., and Gossler, A. (2009). DLL1-mediated Notch activation regulates endothelial identity in mouse fetal arteries. Blood 113, 5680-5688.

Sorensen, L.K., Brooke, B.S., Li, D.Y., and Urness, L.D. (2003). Loss of distinct arterial and venous boundaries in mice lacking endoglin, a vascular-specific TGFbeta coreceptor. Dev Biol 261, 235-250.

Srinivasan, S., Hanes, M.A., Dickens, T., Porteous, M.E., Oh, S.P., Hale, L.P., and Marchuk, D.A. (2003). A mouse model for hereditary hemorrhagic telangiectasia (HHT) type 2. Hum Mol Genet 12, 473-482. 
Struhl, G., and Greenwald, I. (1999). Presenilin is required for activity and nuclear access of Notch in Drosophila.[see comment]. Nature 398, 522-525.

Suzuki, Y., Ohga, N., Morishita, Y., Hida, K., Miyazono, K., and Watabe, T. (2010). BMP-9 induces proliferation of multiple types of endothelial cells in vitro and in vivo. J Cell Sci 123, 1684-1692.

Swiatek, P.J., Lindsell, C.E., del Amo, F.F., Weinmaster, G., and Gridley, T. (1994). Notch1 is essential for postimplantation development in mice. Genes \& Development 8, 707719.

ten Dijke, P., and Arthur, H.M. (2007). Extracellular control of TGFbeta signalling in vascular development and disease. Nat Rev Mol Cell Biol 8, 857-869.

Torsney, E., Charlton, R., Diamond, A.G., Burn, J., Soames, J.V., and Arthur, H.M. (2003). Mouse model for hereditary hemorrhagic telangiectasia has a generalized vascular abnormality. Circulation 107, 1653-1657.

Torsney, E., Charlton, R., Parums, D., Collis, M., and Arthur, H.M. (2002). Inducible expression of human endoglin during inflammation and wound healing in vivo. Inflamm Res 51, 464-470.

Tsujie, M., Tsujie, T., Toi, H., Uneda, S., Shiozaki, K., Tsai, H., and Seon, B.K. (2008). Antitumor activity of an anti-endoglin monoclonal antibody is enhanced in immunocompetent mice. Int J Cancer 122, 2266-2273.

Tsujie, M., Uneda, S., Tsai, H., and Seon, B.K. (2006). Effective anti-angiogenic therapy of established tumors in mice by naked anti-human endoglin (CD105) antibody: differences in growth rate and therapeutic response between tumors growing at different sites. Int J Oncol 29, 1087-1094.

Uneda, S., Toi, H., Tsujie, T., Tsujie, M., Harada, N., Tsai, H., and Seon, B.K. (2009). Antiendoglin monoclonal antibodies are effective for suppressing metastasis and the primary tumors by targeting tumor vasculature. Int J Cancer 125, 1446-1453.

Urness, L.D., Sorensen, L.K., and Li, D.Y. (2000). Arteriovenous malformations in mice lacking activin receptor-like kinase-1. Nat Genet 26, 328-331.

Venkatesha, S., Toporsian, M., Lam, C., Hanai, J., Mammoto, T., Kim, Y.M., Bdolah, Y., Lim, K.H., Yuan, H.T., Libermann, T.A., et al. (2006). Soluble endoglin contributes to the pathogenesis of preeclampsia. Nat Med 12, 642-649.

Vooijs, M., Ong, C.T., Hadland, B., Huppert, S., Liu, Z., Korving, J., van den Born, M., Stappenbeck, T., Wu, Y., Clevers, H., et al. (2007). Mapping the consequence of Notch1 proteolysis in vivo with NIP-CRE. Development 134, 535-544.

Wallberg, A.E., Pedersen, K., Lendahl, U., and Roeder, R.G. (2002). p300 and PCAF act cooperatively to mediate transcriptional activation from chromatin templates by notch intracellular domains in vitro. Molecular \& Cellular Biology 22, 7812-7819.

Wang, J.M., Kumar, S., Pye, D., van Agthoven, A.J., Krupinski, J., and Hunter, R.D. (1993). A monoclonal antibody detects heterogeneity in vascular endothelium of tumours and normal tissues. Int J Cancer 54, 363-370.

Wrighton, K.H., Lin, X., Yu, P.B., and Feng, X.H. (2009). Transforming Growth Factor \{beta\} Can Stimulate Smad1 Phosphorylation Independently of Bone Morphogenic Protein Receptors. J Biol Chem 284, 9755-9763.

Wu, Y., Cain-Hom, C., Choy, L., Hagenbeek, T.J., de Leon, G.P., Chen, Y., Finkle, D., Venook, R., Wu, X., Ridgway, J., et al. (2010). Therapeutic antibody targeting of individual Notch receptors. Nature 464, 1052-1057. 
Xu, J., Krebs, L.T., and Gridley, T. (2010). Generation of mice with a conditional null allele of the Jagged2 gene. Genesis 48, 390-393.

Xue, Y., Gao, X., Lindsell, C.E., Norton, C.R., Chang, B., Hicks, C., Gendron-Maguire, M., Rand, E.B., Weinmaster, G., and Gridley, T. (1999). Embryonic lethality and vascular defects in mice lacking the Notch ligand Jagged1. Human Molecular Genetics 8, 723-730.

Yamashita, H., Ichijo, H., Grimsby, S., Moren, A., ten Dijke, P., and Miyazono, K. (1994). Endoglin forms a heteromeric complex with the signaling receptors for transforming growth factor-beta. J Biol Chem 269, 1995-2001.

Yan, M., Callahan, C.A., Beyer, J.C., Allamneni, K.P., Zhang, G., Ridgway, J.B., Niessen, K., and Plowman, G.D. (2010). Chronic DLL4 blockade induces vascular neoplasms. Nature 463, E6-7.

Yang, L.T., Nichols, J.T., Yao, C., Manilay, J.O., Robey, E.A., and Weinmaster, G. (2005). Fringe glycosyltransferases differentially modulate Notch1 proteolysis induced by Delta1 and Jagged1. Mol Biol Cell 16, 927-942.

Zeng, Q., Li, S., Chepeha, D.B., Giordano, T.J., Li, J., Zhang, H., Polverini, P.J., Nor, J., Kitajewski, J., and Wang, C.Y. (2005). Crosstalk between tumor and endothelial cells promotes tumor angiogenesis by MAPK activation of Notch signaling. Cancer Cell 8, 13-23.

Zhou, S., Fujimuro, M., Hsieh, J.J., Chen, L., Miyamoto, A., Weinmaster, G., and Hayward, S.D. (2000). SKIP, a CBF1-associated protein, interacts with the ankyrin repeat domain of NotchIC To facilitate NotchIC function. Molecular \& Cellular Biology 20, 2400-2410. 


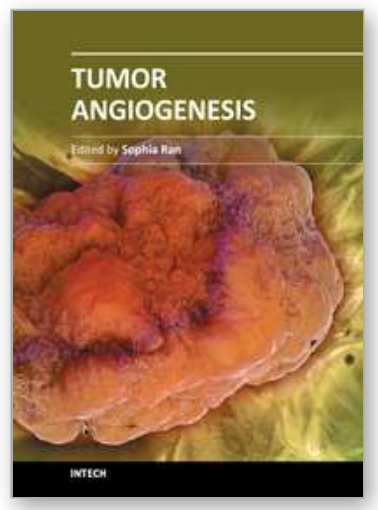

\author{
Tumor Angiogenesis \\ Edited by Dr. Sophia Ran
}

ISBN 978-953-51-0009-6

Hard cover, 296 pages

Publisher InTech

Published online 17, February, 2012

Published in print edition February, 2012

Tumor angiogenesis is the main process responsible for the formation of new blood vessels that promote tumor growth and metastasis. This process is driven by potent pro-angiogenic factors that are predominant in the tumor environment and are produced by both malignant cells and the host cells recruited to the tumor site. Tumor environment is characterized by the imbalance between pro-angiogenic and anti-angiogenic factors, which drives the construction of numerous but structurally defective vessels. These poorly perfused and abnormal vessels significantly contribute to the tumor pathology not only by supporting the expansion of the tumor mass but also by promoting chronic inflammation, enhancing thrombosis, impeding drug delivery, and disseminating tumor cells. These problems associated with tumor vasculature continue to attract great attention of scientists and clinicians interested in advancing the understanding of tumor biology and development of new drugs. This book complies a series of reviews that cover a broad spectrum of current topics related to the pathology of tumor blood vessels including mechanisms inducing new vessels, identification of new targets for inhibition of tumor angiogenesis, and potential clinical use of known and novel anti-angiogenic therapies. The book provides an update on tumor angiogenesis that could be useful for oncologists, cancer researchers and biologists with interests in vascular and endothelial cell behavior in the context of cancer.

\title{
How to reference
}

In order to correctly reference this scholarly work, feel free to copy and paste the following:

Olivier Nolan-Stevaux and H. Toni Jun (2012). Beyond VEGF: The NOTCH and ALK1 Signaling Pathways as Tumor Angiogenesis Targets, Tumor Angiogenesis, Dr. Sophia Ran (Ed.), ISBN: 978-953-51-0009-6, InTech, Available from: http://www.intechopen.com/books/tumor-angiogenesis/beyond-vegf-targeting-alternativetumor-angiogenesis-signaling-pathways-

\section{INTECH}

open science | open minds

\section{InTech Europe}

University Campus STeP Ri

Slavka Krautzeka 83/A

51000 Rijeka, Croatia

Phone: +385 (51) 770447

Fax: +385 (51) 686166

\section{InTech China}

Unit 405, Office Block, Hotel Equatorial Shanghai

No.65, Yan An Road (West), Shanghai, 200040, China 中国上海市延安西路65号上海国际贵都大饭店办公楼 405 单元

Phone: +86-21-62489820

Fax: +86-21-62489821 
www.intechopen.com 
(C) 2012 The Author(s). Licensee IntechOpen. This is an open access article distributed under the terms of the Creative Commons Attribution 3.0 License, which permits unrestricted use, distribution, and reproduction in any medium, provided the original work is properly cited. 